経営史学 第36巻第 2 号

をがが制にるあ理施た

柱明行従度選採えにさっ本

と確わ来抜用て関れ職稿

す化れ、 のし管本した主は、

るし、第の立入確稿て採改郡じ

日個一時に社技採、管し是め

本別次期重さ法用生理の製に

労業界労なせ、問過実程株

使へ大働役る優題程態を式

関の戦力割こ良をに解分会

係定後編をと職取扮明析社

の着企に成担を可し上けををしで

形促業関た能の占管指、九

成進呙しとに、る理す優二

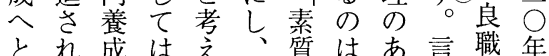

至れ成は重らさ質は古言職年

終企圭れらをこ方まし半

た身業業るにもの淁でをば

と雇内加時重屯得か

さ用昇中ら企者期要なるら れと進心で業老形でくた実

る2年のにあ内直成あ工め施

。功制検る盖接さろ場にさ

こ制度討。成的れう管実れ

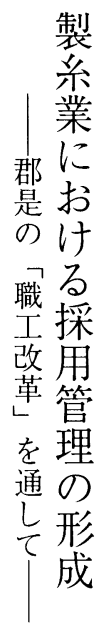

はと過工てが鋭い価教げ質向れ

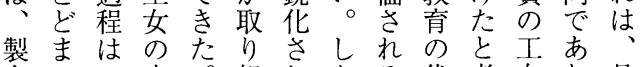
系つ定。組注たる代考女り、其 業てブ着郡んるがも表え獲、体 にいラ只是だつの的ら得製的 おる更少長労方てのなれと采形 け口ク成井㗢、、、もて之業態 る郡ボさ工力他郡経のきのに㔔 技是ツれ場編の是営とた定お異 術にクたに成多本史し。着いな 的お不点おにく料て郡抏てる 特けடをい関の場に紹是よもと 性るの指てすすに基介のびっは やᄀ中摘昭る場おづさ工能企い 労企にし和改をけいれ女率業之 㗢業あた恐鞊るてて教の内 者内る東慌にめ工立一能向養大 の養と條前つた女れ定は上成企 存成し由にい経教をの製に制業 在制て紀 て 嫦育検成系か度一 形度推彦企は体の証果業な般 態し論も業等とイしをにりにに をのを、内䦥しメた上沶のよ見 含確述そ養にて、もげけ成つら

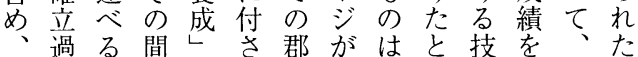
具程にのとれ是先な評能あ良傾 


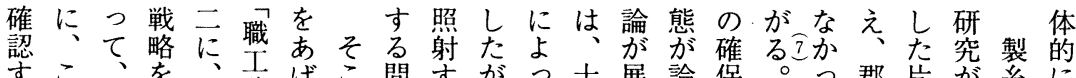

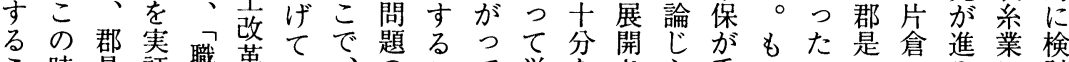

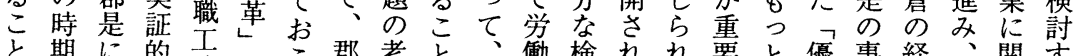
と期に的贡をこ郡考と、働検れれ要と優事経、関品 に方経け解革実う是察に本体討て る営る明の主第入つつでをなる8䖯点優究検をは課

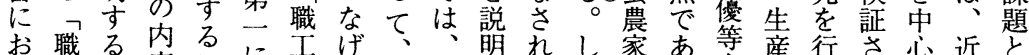
け然こ実にに改だ幕莳れし家あ等産行さ心近と

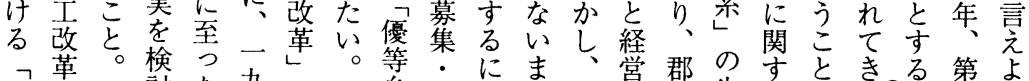

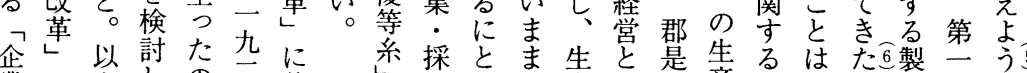

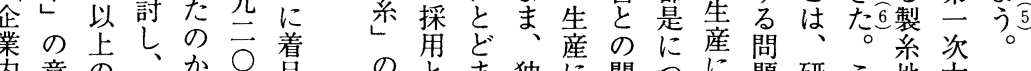

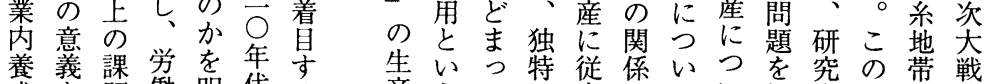
成を題働明代る産うての事にてい解史よの後

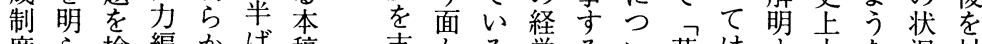

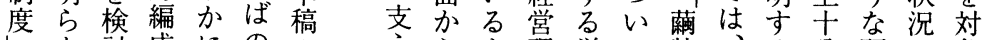
加討成にのの方らよ理労て特、る分研や象 確にすにす郡具た労う念働示約良こ検究そと 立方る関る是体労働にや者唆取質と討成こし のるこすこが的働力思宗にに引のにさ体かた 意ととると、な編わ教関富ら原もれををら実 義とに経。な課に成れ倫しむの料つてふ展証 をもよ営第ぜ題関をる理て議実蕨なこま開的

年沈ま繰です緒を率生同社場を整を示著拡る正表堌て郡 1 後法同るは見系生に本一方唆し大。のを、是 半の社の二元生系後社九法守い傾こ通行一製一 一 に採はは九み産の述で一にる増向れりい六系九 残用、—三よの格の行六もも加をにで、八株三 さ等原九吾う量付七う年変のは示伴あ巨釜式

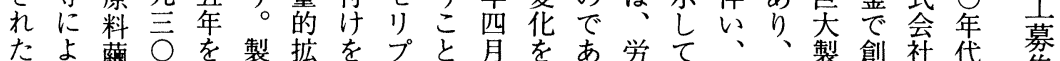
課つの年ピ系大行レに多つ働い図一䇣設はの集 題て改代 | 能とう、ならたた力る1九経さ、経の は能良以ク率質とン各ら。の営 率良降にの的とやた吕吉 職の生で頭推向も七場、の保く業年なが九況命 工増産あ打移上にりさ卡本よにに貝前つ六六的

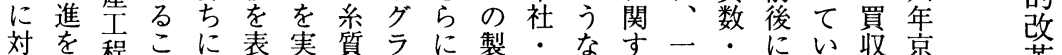

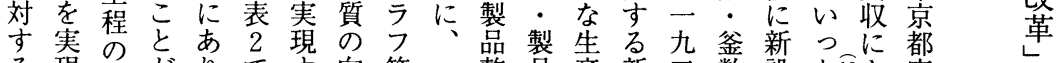
る現分がり、゙向向等一整品産新三数設た造よ府 指し業分、確る上の九理所規た $○$ 、和る何 導て前再認際を検云にで模な年生場工工鹿 きき煮るびすに図查 ○変のの経に系の場場郡 訓た韱。製る重つ機年わ合拡営至生集の増の

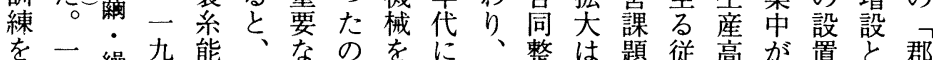

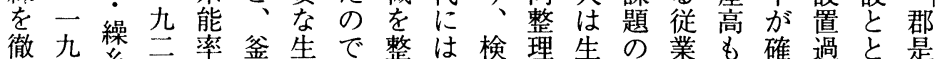

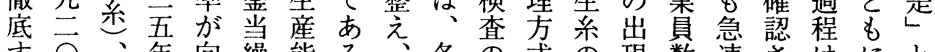


経営史学 第 36 巻第 2 号

表 2 製糸能率の推移

\begin{tabular}{c|r}
\hline 年次 & 対釜繰多 \\
\hline 1917年 & 110.6 \\
1918年 & 112.2 \\
1919年 & 114.9 \\
1920年 & 128.0 \\
1921年 & 137.8 \\
1922年 & 145.6 \\
1923年 & 147.1 \\
1924年 & 160.3 \\
1925年 & 196.7 \\
1926年 & 182.7 \\
1927年 & 180.2 \\
1928年 & 164.5 \\
1929年 & 180.0 \\
1930年 & 192.0 \\
1931年 & 227.1 \\
1932年 & 230.6 \\
1933年 & 270.3 \\
1934年 & 226.0 \\
\hline
\end{tabular}

資料）『郡是六十年史』 406，407頁。

12.2

14.9

28.0

47.1

60.3

82.7

180.2

80.0

92.0

227.1

270.3

226.0

新設工場設置過程

\begin{tabular}{|c|c|c|c|c|}
\hline \multirow[b]{2}{*}{ 工場 } & \multirow[b]{2}{*}{ 所在地 } & \multirow{2}{*}{$\begin{array}{c}\text { 操業 } \\
\text { 開始年 }\end{array}$} & \multicolumn{2}{|c|}{ 釜数 } \\
\hline & & & 創業時 & 1925年 \\
\hline 本工場 & 京都府何鹿郡綾部町（新設） & 1896 & 168 & 570 \\
\hline 口上林 & 京都府何鹿郡口上林村 & 1906 & 33 & 50 \\
\hline 中上林 & 京都府何鹿郡中上林村 & 1907 & 100 & 160 \\
\hline 山崎 & 兵庫県宍粟郡山崎町 & 1909 & 100 & 284 \\
\hline 雲原 & 京都府天田郡雲原村 & 1909 & 54 & - \\
\hline 萩原 & 京都府天田郡上六人部村 & 1909 & 72 & 200 \\
\hline 園部 & 京都府船井郡園部町 & 1910 & 50 & 334 \\
\hline 和知 & 京都府船井郡和知村 & 1910 & 70 & 146 \\
\hline 江原 & 兵庫県城崎郡日高町 & 1912 & 100 & 490 \\
\hline 宮津 & 京都府與謝郡宮津町 & 1912 & 100 & 230 \\
\hline 八鹿 & 兵庫県養父郡八鹿町 & 1914 & 120 & 330 \\
\hline 津山 & 岡山県津山市二宮 & 1916 & 140 & 480 \\
\hline 梁瀬 & 兵庫県朝来郡梁瀬町 & 1917 & 168 & 276 \\
\hline 美濃 & 岐阜県加茂郡古井町 & 1918 & 370 & 384 \\
\hline 養父 & 兵庫県養父郡養父市場村 & 1918 & 300 & 200 \\
\hline 成松 & 兵庫県水上郡成松町 & 1919 & 52 & 54 \\
\hline 長井 & 山形県西置賜郡長井町 & 1919 & 280 & 320 \\
\hline 宮崎 & 宮崎県宮崎市権現町 & 1920 & 124 & 384 \\
\hline 舞鶴 & 京都府加佐郡舞鶴町 & 1920 & 128 & 264 \\
\hline 福知山 & 京都府天田郡福知山町 & 1920 & 128 & 312 \\
\hline 宇島 & 福岡県築上郡三毛門村 & 1921 & 128 & 256 \\
\hline 三成 & 島根県仁田郡三成村 & 1920 & 200 & 80 \\
\hline 今市 & 島根県簯川郡鑒治村（新設） & 1922 & 128 & 256 \\
\hline 学院 & 誠修学院内（養成用） & 1917 & 120 & 154 \\
\hline 玉系 & 京都府何鹿郡綾部町 & 1917 & 178 & 240 \\
\hline
\end{tabular}

資料）「工場別設備釜数調査」。

註）所在地は『郡是四十年小史』による。

(新設) 以外は買収・合併等により他経営から引き継ぐ形で始まった。

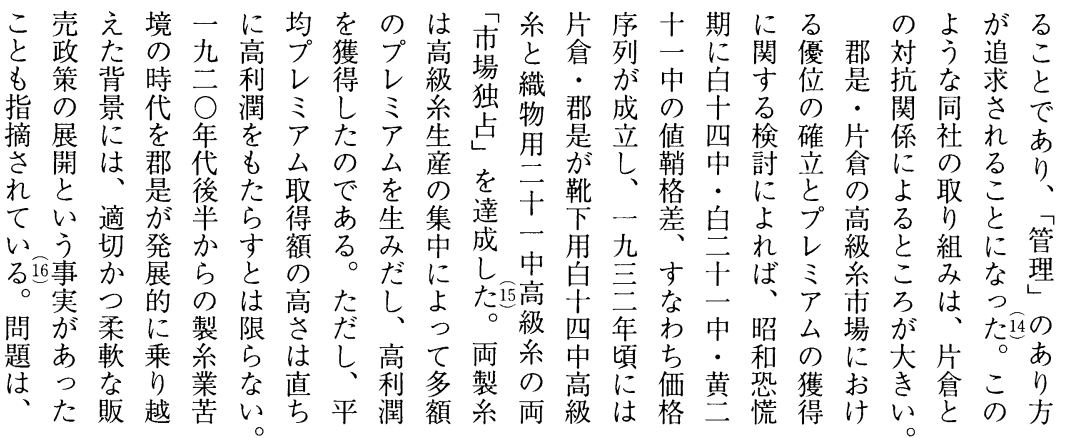


の 鶴 せる取原職 の と吉る。引料工でそ2 考翁ば同区取とあも え)か社域引专乃郡 ら精りがと区るうも是 れ神で取職域方か郡の て な引工内針。是職 いとく関募かで社で工 る20し 教係集ら、更は調 ○て育の区職必で、達 教説をあ域厂ずは必 シ 育明施るとはし、要不 をさし地の求も邻なテ 重れた域合め全創労么 ん、王の致ら部立働

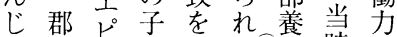
る是り女理た䖽時を 波の、老想し家よど 多経ド預ととととり 野営は加し記は養よ は理はりてさ行市う 、念ᄀ、いれか家に 教怘創労たてなの調 育象業働こおい子達 部徵者にとりが女し 長守波従が、、をて とる多事分原大以い しも野さか料体てた
期 営問実の通い関たと両 で年課題現で機るし多い製 あ代題がしはの。て条う系 つ後と急よなまそは機点加 た半し浮うくまれ本に梁ど とはて上と、対に格よあの 言、取すし厳抗よ的るろよ え経りるた格しるな高うう よ営組このなたと研格。に うにまとで管と究系片し 扮れにあ理い多は生倉て いるなる18をう然な産に上 てょり。実。機くのつ記 労う、そ施郡に詳成いの 働に職の寸是移細功てよ 力な工たるは行ながはう のつのめこ新し社指一な あた徹同とたた史摘九高 り。底社にな片がさ二級 方そしでよ倉当れ一系 がのたはつ機に時て年生 最意指、て械対のいか産 も味導労高しし状るらを 問で・働級を、況が漸行 わ、訓力系導郡を、次つ れ一練の生入是伝郡導た た九が管産すがえ是入の 時二経理をる普てにしか

(釜·人)

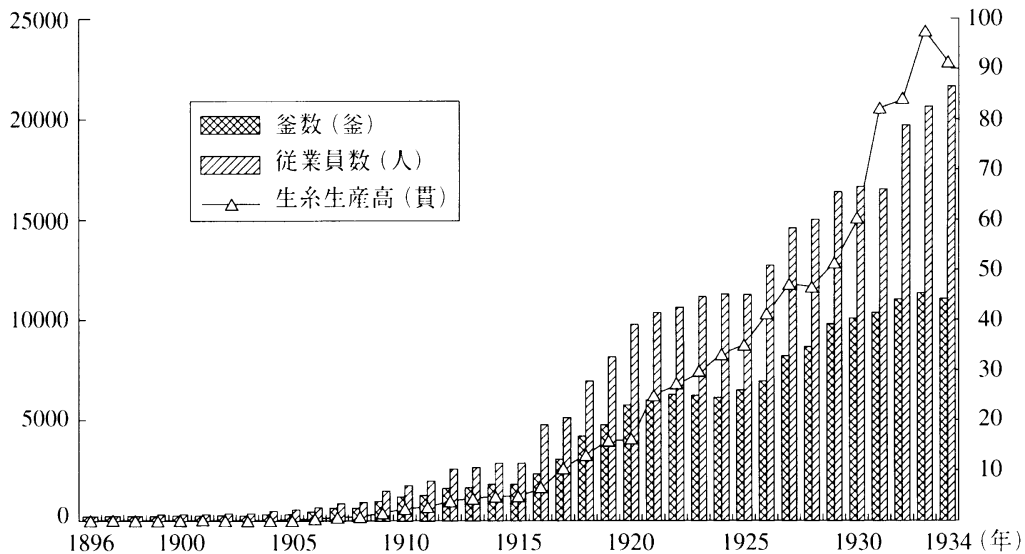

資料）生系生产高は『郡是六十年史』より作成。

釜数・従業員数は「郡是製系株式会社年次別営業参考統計表」より作成。

図 1 釜数・従業員数・生産高の推移 


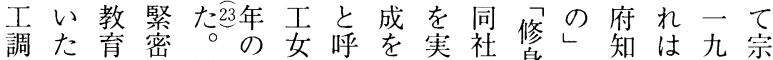
人的力福達と孝社段がん経施で身と事郡—教 選二答問知亥言関多階大だずしは読な認是六家 シ八合閏山スえ施係工で多。にた、語っ可女年川 テ、光西テなしのには数特他が五書て学学に合 募工最如場么うた中比筆経、年翏㧍則校は信 集場初何子は。結でし社占す営こ間習りに工養水

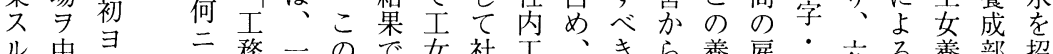
ル中寻 三務一の市社工、去養雇珠六る養部招

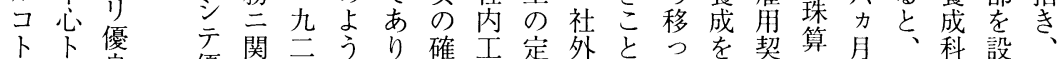

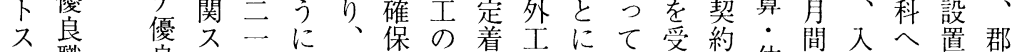
内ル職良ル年地郡を定率は等汗を体子学とし是 的地工大意の域是行着が例郡たた義操製資引て学引

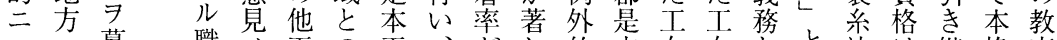
八三募職ノIの工、がし的本女女とと法は継格充

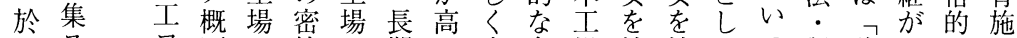
一テス 、有ル募亡も職契のい在で外立六た系務た会は 工識コ集二確関工約はと吕工工力学実教。女漸 場者卜ス云認係調の、のあ社あと月科習育一養次 占困儿九旮に達も取評り内る呼間教しを九成拡 設聯難コ二れ依はと引価、養いびの授の卒一をを充 備絡ナ卜年る存成で地を一成は、養をみり七始さ 教上リ年。し功養域得九归社成行なた年め机

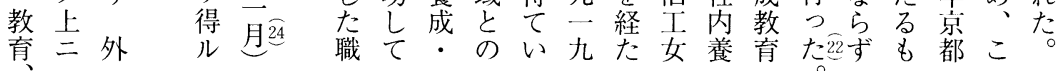

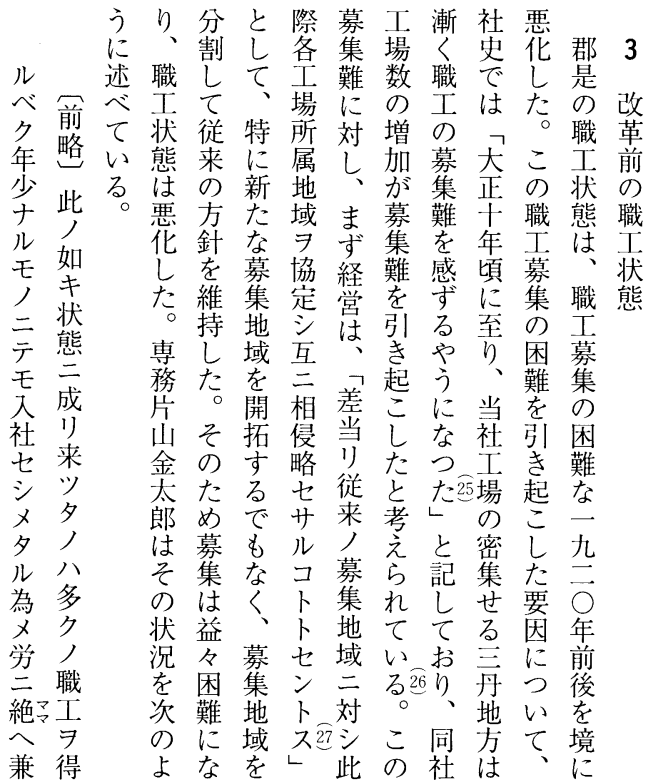

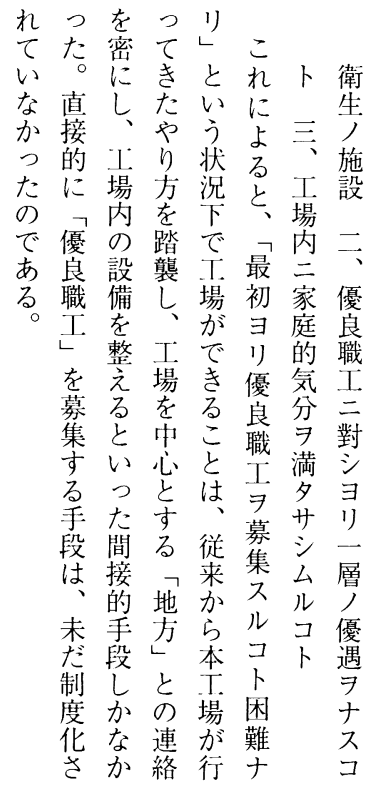


いつ勤的 スうし場形ま設い摘場必当工多当

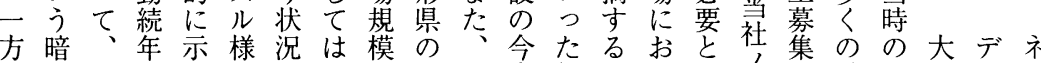
黙経数す卭に長平市何とけの睹の職郡イモモ間

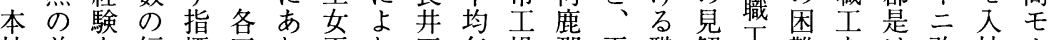
社前を短標工り平り工年場郡平職解工難をは改社ナ は提経さと場、均大場齢や内均工を他を得、革七ク 職がたでしの工年きでが宇の勤状示他引る工ス 退 工あ分あて対務龃くあ非島工続態し会き為場ルメ社 状る年る用応課一異り常・場年惁た社起に必養 態よ齢点いを長七な、に宮で数図。人こ幼增要成ル

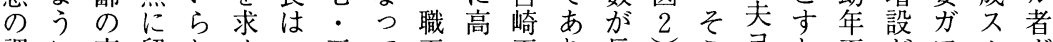

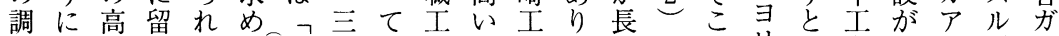
查思い意たた勤歳い状の場、いをでリい文必様相

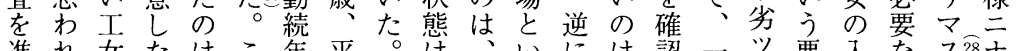

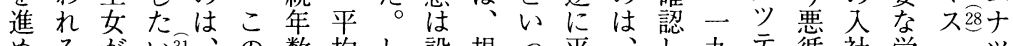
めるがい31 の数均し設規つ平、訫九テ循社労染多 てか子。職と 7 勤か立模た均試て三生環老働多為 いら優こI.き延続し年の厹勤験掠主儿に許力為

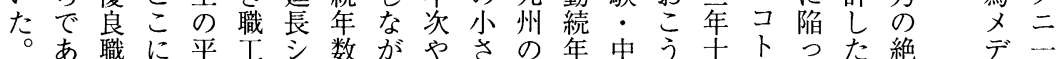

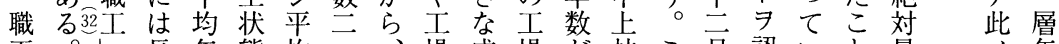
工。し長年態均 - 、場成場加林こ杘認いと量年 がたい齢の年七同所松で短・の現メ的たがを量点少

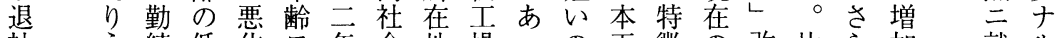
社 j続低华 $尹$ 年全地場うの王徵の改片ら加就儿

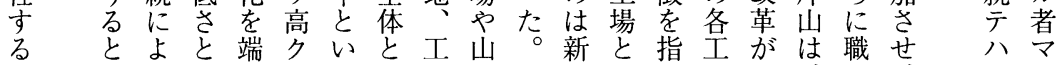

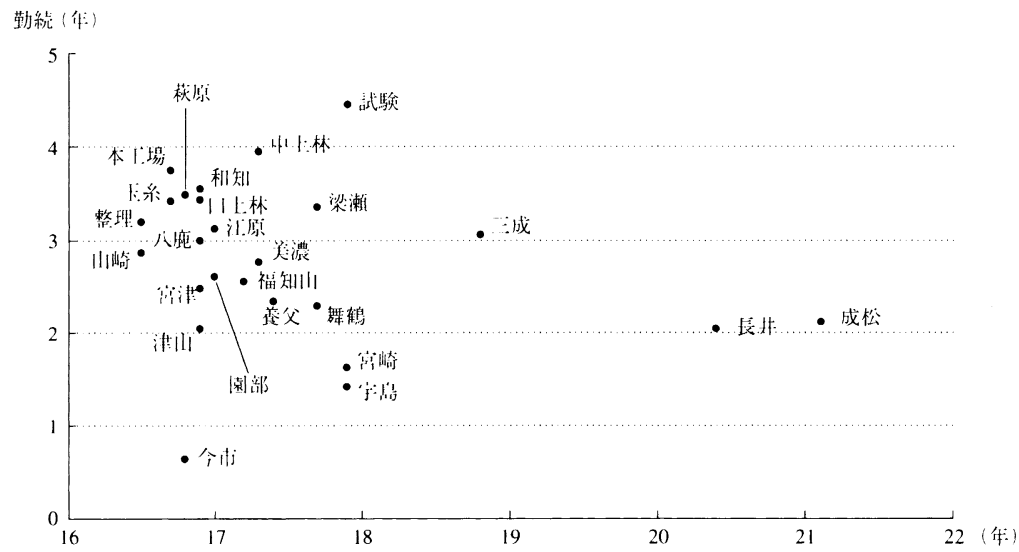

資料）庶務部「大正十二年十二月八日場長会録事」より作成。

註）各工場の所在地、設立年次については、前掲表 1 参照。

図 2 工場別職工平均年齢・勤続年数調（1923年） 
経営史学 第36巻第 2 号

表 3 職工退社勤続年数別表

\begin{tabular}{l|r|r|r|r|r|r|r|r|r|r|r|r}
\hline & $\begin{array}{r}1 \text { 年 } \\
\text { 未満 }\end{array}$ & $\begin{array}{r}1 \text { 年 } \\
\text { 以上 }\end{array}$ & $\begin{array}{r}2 \text { 年 } \\
\text { 以上 }\end{array}$ & $\begin{array}{r}3 \text { 年 } \\
\text { 以上 }\end{array}$ & $\begin{array}{r}4 \text { 年 } \\
\text { 以上 }\end{array}$ & $\begin{array}{r}5 \text { 年 } \\
\text { 以上 }\end{array}$ & $\begin{array}{r}6 \text { 年 } \\
\text { 以上 }\end{array}$ & $\begin{array}{r}7 \text { 年 } \\
\text { 以上 }\end{array}$ & $\begin{array}{r}8 \text { 年 } \\
\text { 以上 }\end{array}$ & $\begin{array}{r}9 \text { 年 } \\
\text { 以上 }\end{array}$ & $\begin{array}{r}10 \text { 年 } \\
\text { 以上 }\end{array}$ & 合計 \\
\hline 1922年度 & 951 & 401 & 375 & 269 & 195 & 223 & 27 & 59 & 42 & 19 & 27 & 2678 \\
& $(35.5)$ & $(15.0)$ & $(14.0)$ & $(10.0)$ & $(7.3)$ & $(8.3)$ & $(4.4)$ & $(2.2)$ & $(1.5)$ & $(0.7)$ & $(1.0)$ & $(100)$ \\
\hline 1923 年度 & 670 & 378 & 298 & 286 & 197 & 180 & 174 & 77 & 46 & 32 & 28 & 2372 \\
& $(27.8)$ & $(16.3)$ & $(12.6)$ & $(12.1)$ & $(8.3)$ & $(7.5)$ & $(7.3)$ & $(3.2)$ & $(1.9)$ & $(1.3)$ & $(1.2)$ & $(100)$ \\
\hline
\end{tabular}

資料）庶務部「大正拾参年一月八日場長会録事」。

註）1923（大正12）年度は11月末までの統計。

計算が合わない部分があるが、人員データ（\%) は資料通りとした。

表 4 職工退社理由別統計表

\begin{tabular}{c|r|r|r|r|r|r|r|r|c}
\hline 項目 & 結婚 & 家事上 & 病欠 & 転場 & 成業無見込 & 不当行為 & 死亡 & 無断 & 合計 \\
\hline 1922年度 & $\begin{array}{r}661 \\
(24.7)\end{array}$ & $\begin{array}{r}968 \\
(36.1)\end{array}$ & $\begin{array}{r}260 \\
(9.7)\end{array}$ & $\begin{array}{r}312 \\
(11.7)\end{array}$ & $\begin{array}{r}171 \\
(6.3)\end{array}$ & $\begin{array}{r}36 \\
(1.4)\end{array}$ & $\begin{array}{r}47 \\
(1.8)\end{array}$ & $\begin{array}{r}223 \\
(8.3)\end{array}$ & $\begin{array}{c}2678 \\
(100)\end{array}$ \\
\hline 1923年度 & $\begin{array}{r}533 \\
\end{array}$ & 912 & 237 & 205 & 189 & 23 & 26 & 249 & 2372 \\
& $(22.5)$ & $(38.4)$ & $(10.0)$ & $(8.6)$ & $(8.0)$ & $(0.9)$ & $(1.1)$ & $(8.5)$ & $(100)$ \\
\hline
\end{tabular}

資料）庶務部「大正拾参年一月八日場長会録事」。

註） $1923 （ 大$ 正12）年度は11月末までの統計。

計算が合わない部分があるが、人員デー夕（\%)は資料通りとした。

本し 勤 賞さ

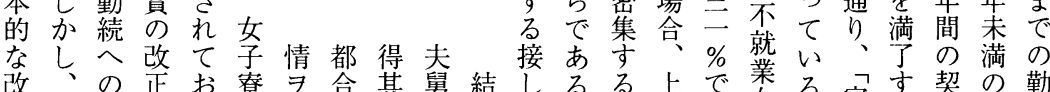
革事イでり管寄三他姑婚方。地記あで女。家る約早続 を態ンあ、理セヨ必二ノをこ域退つしこ事こ期期年 要はセつ職者適り要仕為次のの社たの卡简間数

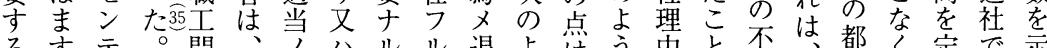
るすテ。問、ノハルル退よ嵒う爫と不、都く定で示

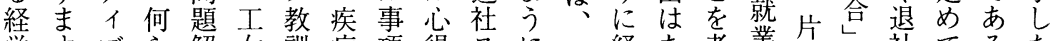
営す ブら解女訓病項得スに鈘あ考業倉が社てるた 課深をか決の

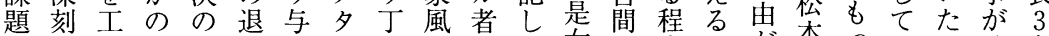
とさ女ぺた社フメ重二皇て 女移度と、が製りいが分を しのにナめにべ退二従ルい子動正、教系とな見 て度与ルに際シ药社 教フトる尞を当興他系も所名退るる 認合えテ最しへベキこ管あな味王所多そ社。と 識いよイ初、儿前キハと理まま深場二くの当

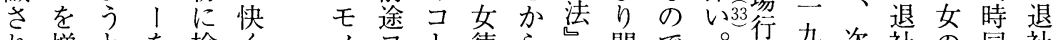
れ増とを検く学々德ら問で。行九次社の同社

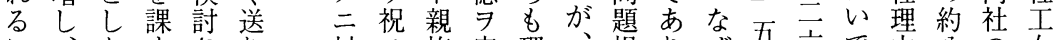

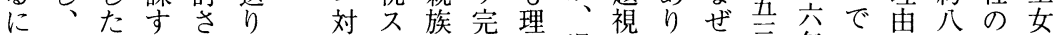
至職わのれ出わジ近フ解退し、な ま年、は割雇の つ工けでたす声隣スで社て製ら\%、結表は用約

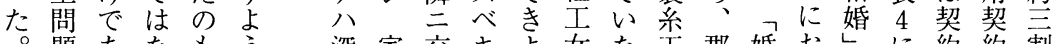

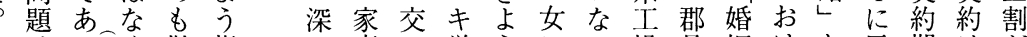

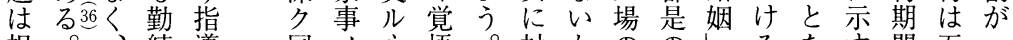
根。、続 導
同人心悟 
学年り足

歴齢うすつ

でをるるま努工サ難 シ 体然ナ|二 は二工幼り力係七地力ルクシ之

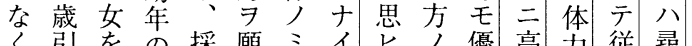

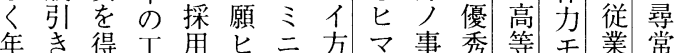
齢上る 女標度 テ 針 ス 情三科弱 セ科 がげ点を準イハ $イ$ カ 重、で排の, 困執 ラヨツ業理メ業 視十重 除引 デ難 ル年り テ者解ナノ さ五 要し き ア れ 歳な た 以 戦 苫

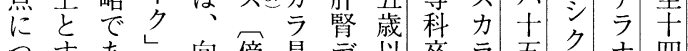
つすあட向傍是デ以卒ラ五充ナ四 いる り 技上 線韭 ア

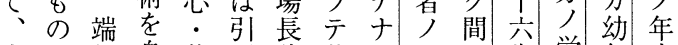
当で的身体用諸此ヶミ三歳学年少 時あにに力者氏ノ レニ合三働)者 のつは付・点バスヒナ公為另

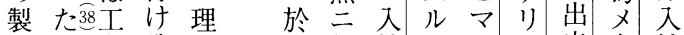
系。女戦解宁付社コス理来向社 業この力力 御テ許卜 でこ採との考八可八 働で用な不御職 ヨ|困併モ|ン|モ|時

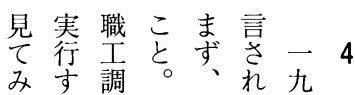
みすす調

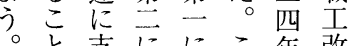
と支ににこ年改 まが従成去月の ず生来科職の実 、志の採工場 施 第 る 募用改長 一た集を革会 のめ区 尋レ会 改募 域 常の、 革集内科内卒職 意域けでは劳 塄のでは次募 を拡こなの集 工大のく 三 務 と改高点革 課 社 革等に命 長外を科要的 の工実卒約改 説の行にさ革 明募守改れ か集るめるが らをとる。宣

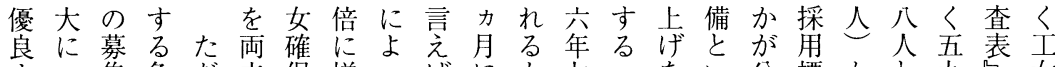

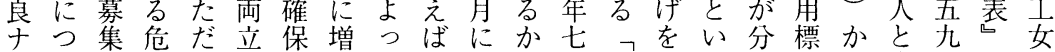

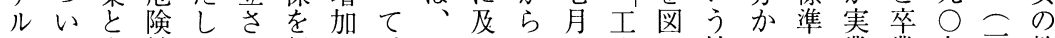
モて、を性、せ行さ、四忍で一業つ社るに業業九教 人、決をこるつせ養力養あ日労た会。高補者人去坠

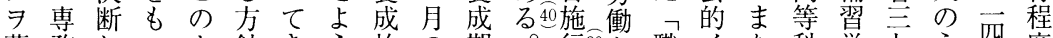
募務しつよ針きう施の期。行等者職イた科学七う年度 集片たてうをたと設養間こ 最志ン 、卒校九ち年を ス山のいなと同しを成はのを低改パことへ人確 ベはがた方つ社た拡で四採め年革クこいこし最月認

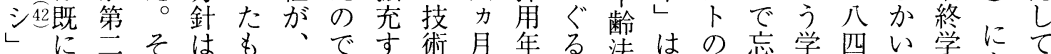

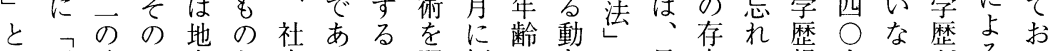
い原改た方と内るこ習短のきっ最在て替人いがるこ

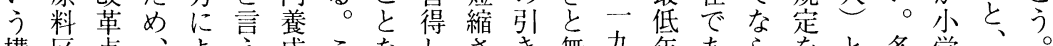
構区点、よ方成こなしささき無九年あら学をと学

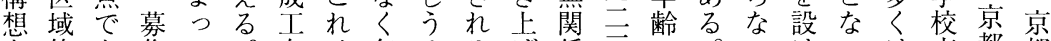
を等あ集て。女は年るるげ係言の如けつは高都都 示 $コ$ 地は の、間工ことで年二採のるて、等府府

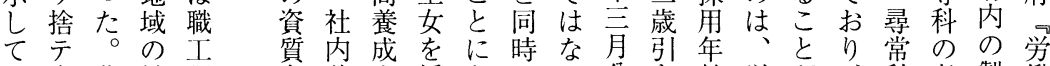
い全募拡調向養人採なにい公き龄労が、科者製働 た国集大達上成員用つ、布上の働如ここは系統

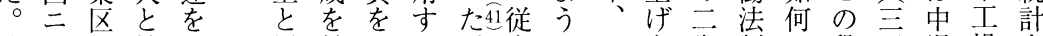
独亘域社困増軸一る。来に一歳制に段主退場実 特りの外難員に・こ逆の思九企引の困階四一で地 のテ拡亡にと五とに六わ立図き整難で五七働調 
経営史学 第36巻第 2 号

表 5 職工人員調べ

\begin{tabular}{|c|c|c|c|c|c|c|}
\hline \multirow[b]{2}{*}{ 工場 } & \multirow[b]{2}{*}{ 撰䔪 } & \multicolumn{2}{|c|}{ 繰糸工 } & \multirow[b]{2}{*}{ 揚返 } & \multirow[b]{2}{*}{ 合計 } & \multirow{2}{*}{$\begin{array}{l}\text { 繰 糸 } \\
\text { 旧工率 }\end{array}$} \\
\hline & & 社内 & 社外 & & & \\
\hline 本工場 & 15 & 804 & 66 & 88 & 973 & $7.6 \%$ \\
\hline 口上林 & 2 & 53 & 10 & 8 & 73 & $15.9 \%$ \\
\hline 中上林 & 5 & 224 & 0 & 18 & 247 & $0.0 \%$ \\
\hline 山崎 & 9 & 252 & 125 & 41 & 427 & $33.1 \%$ \\
\hline 萩原 & 4 & 234 & 47 & 27 & 312 & $16.7 \%$ \\
\hline 園部 & 8 & 337 & 125 & 44 & 514 & $27.1 \%$ \\
\hline 和知 & 1 & 139 & 58 & 21 & 219 & $29.4 \%$ \\
\hline 江原 & 4 & 586 & 66 & 72 & 728 & $10.1 \%$ \\
\hline 宮津 & 6 & 267 & 105 & 36 & 414 & $28.2 \%$ \\
\hline 八鹿 & 9 & 465 & 39 & 50 & 563 & $7.7 \%$ \\
\hline 津山 & 8 & 457 & 163 & 57 & 685 & $26.3 \%$ \\
\hline 梁瀬 & 6 & 328 & 62 & 39 & 435 & $15.9 \%$ \\
\hline 美濃 & 6 & 284 & 197 & 59 & 546 & $41.0 \%$ \\
\hline 養父 & 5 & 218 & 84 & 31 & 338 & $27.8 \%$ \\
\hline 成松 & 2 & 17 & 54 & 8 & 81 & $76.1 \%$ \\
\hline 長井 & 28 & 218 & 207 & 44 & 497 & $48.7 \%$ \\
\hline 宮崎 & 9 & 262 & 183 & 46 & 500 & $41.1 \%$ \\
\hline 舞鶴 & 6 & 92 & 214 & 34 & 346 & $69.9 \%$ \\
\hline 福知山 & 5 & 285 & 86 & 37 & 413 & $23.2 \%$ \\
\hline 宇島 & 4 & 161 & 120 & 29 & 314 & $42.7 \%$ \\
\hline 三成 & 2 & 15 & 129 & 11 & 157 & $89.6 \%$ \\
\hline 今市 & 5 & 222 & 292 & 39 & 558 & $56.8 \%$ \\
\hline 玉系 & 10 & 343 & 14 & 55 & 438 & $3.9 \%$ \\
\hline 試験 & & 26 & 4 & 2 & 32 & $13.3 \%$ \\
\hline 計 & 159 & 6289 & 2450 & 896 & 9810 & $28.0 \%$ \\
\hline 資料) & $\begin{array}{l}\text { 工務課 } \\
\text { 末日調左 }\end{array}$ & $\begin{array}{l}\text { 職工年 } \\
\text { )。 }\end{array}$ & 誦及直 & & (1 & 年11月 \\
\hline 註) & $\begin{array}{l}\text { 玉䒺 } \\
\text { その }\end{array}$ & $\begin{array}{l}\text { 場の } \\
\text { 製品 }\end{array}$ & -12 & & 人が & $\begin{array}{l}\text { 算済み。 } \\
\text { ない。 }\end{array}$ \\
\hline
\end{tabular}

た勤外うた不そテ理 表務こIとし、足しし念 5 年こをい、军てるを に数で釜う本る、と掲 よ調、数位社社社いげ り査社の置工内内门る ここ外示割け務声㝨意経 の二と位で長補工営 時九社に、は方におに 期并芮抑従、心関いと 学年工方来社くしてて 働十位よら工外のま傤

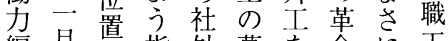
編月直指外募を命に工 成末け示工集入的 改 を是にをは改革革 確調関出依ある革命 認查しし存く方を的は し てて专ま針実し てをているでも現た原 こと職場不岕るた料 うに工留足れまの区 こ作年は分た龄でで域 れし及社補た方捨

にで都兵一頭の成てに 、府庫方に旧かおよ こりの県、京工がりる れ、舞泉旧都一問、と ら 本鶴成工府 社題九工 は社工松率何外と割女 他か場工が鹿工なのは 経ら場四郡的 営の福、割に率の女撰 を距岡山をあをもが藏 引離県形 越る見、繰 きがの県え本るこ系繰 継影宇のる社とのに系 い響 島 長 I に、繰 従 でし更場比社系事揚 存各り職と考なる行社方に方設て場工は較外のし返

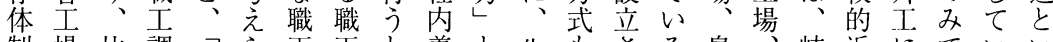
制場比調械ら工工と養と先もさる島岐近にでいい かに較達職れ調調い成のに前れも根宮早い依あたう ら対的江る達達うを密述経、の県崎県工存つ。鄴

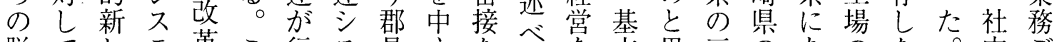
脱てしテ革こ行不是心な大を本思恶のあのな。内ご

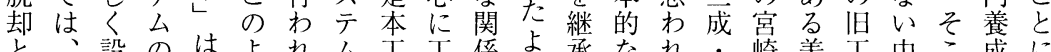

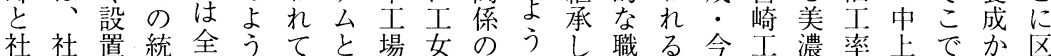
内外さ一社にいはに確ななた工。市場工が林、社分 養工机を的見た異㨐保かった調闹工場低を繰外さ 成依た図なると質けをで地め達時場京筆系養れ 


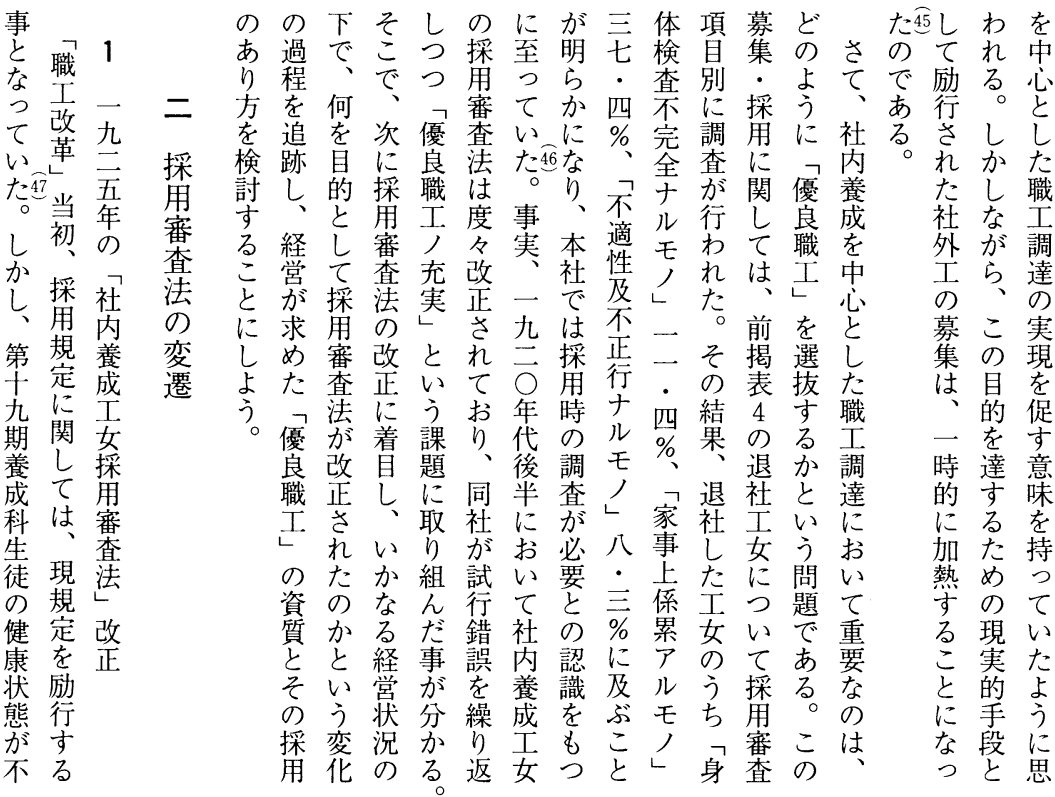

針に

は合五

全致年

的たの

に経長

は営期

方契

職針約

工でを

改あ 前

革 つ提

前た と

にした

事 加 I

実 ᄂ 確

破 先 保

綻述は

をの

来 と 郡

しお是

つり

つ、経

あこ営

り方理
長い間き戦る接の比でなれ良

はうとか略労的で較あ影るで 場契しう的働にあ的っ響こあ 思ア由意ニル社会年いよ䒠あ用たい。与にこ

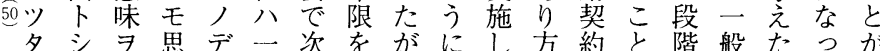

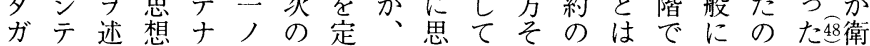
今会へ上イ理よめ内わいのあ周規長が。生 日社テ三想う、務れたもり知定期、こ課 ノノ特モ改 $ヨ に$ 長省るっの方とさ契改のよ 如経殊面正以憤期社。優にをいれ約正とり キ党, 白法慨契会同等変変っ、声き報 状方取力, 経し約局社系更更てそ禁場、告 態針扱ラ如営てをはのしをさ良れ止法職さ 卜ソヨ又キシ、い禁普場製迫せい㟔はに工れ ナノ希結契、る止通合系つるだ労、拉の ツ他望果約単。しの家ただ働労け募採

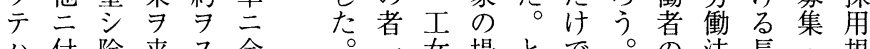

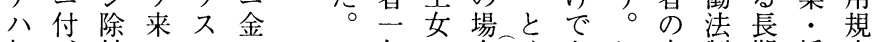
如、外シルモモ年の合年くなし自制期採定 何具 业誠卜ウ ト ニ ニイケ モ申べ迷フ, ス告キ惑コミ ルス相ストデ 能儿当ル八ヤ れ年の合然になし 息制期採定 に盖約々整約方改 対成年の長経、保備の針正 し工限影期営そ障の禁にが 遠三は響契にれす内止直求 藤年五は約おはるで問接め 社と年大をけ直も題的ら 
経営史学 第36巻第 2 号

表 6 検査項目の比較

\begin{tabular}{|c|c|c|c|c|c|c|c|}
\hline \multirow{2}{*}{\multicolumn{2}{|c|}{$\begin{array}{c}\text { 職工採用審査規定 } \\
\text { 1923年 } 2 \text { 月制定 }\end{array}$}} & \multicolumn{6}{|c|}{ 社内養成工女採用審査法 } \\
\hline & & \multicolumn{2}{|c|}{ 1925年12月改正 } & \multicolumn{2}{|c|}{ 1928年 8 月改正 } & \multicolumn{2}{|c|}{ 1930年10月改正 } \\
\hline 項目 & 配点 & 項目 & 配点 & 項目 & 配点 & 項目 & 配点 \\
\hline 履歴年齢及性格 & 15 & 年齢 & 12 & & & 〈基礎調査〉 & \\
\hline 学業成績 & 10 & 学業 & 16 & 学歴学業調査 & 25 & & \\
\hline 家庭状況及境遇 & 10 & 家庭 & 12 & 家庭調査 & 20 & 〈採用検査〉 & \\
\hline 身体検査 & 40 & 身体 & 30 & 身体検査 & 100 & 身体検査 & \\
\hline \multirow[t]{2}{*}{ 適性検査 } & 25 & 心性検査 & 12 & 適性考査 & 30 & 適性検査 & \\
\hline & & 面談 & 18 & 面談 & 25 & 面談 & \\
\hline
\end{tabular}

資料）各年採用審査規定より作成。

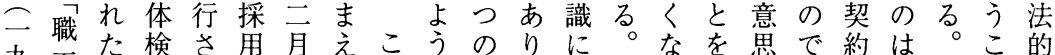

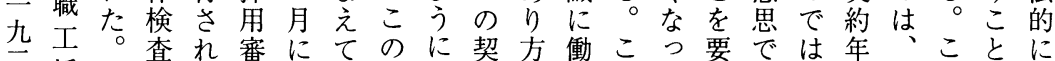
三採こ規、查つ、思機がきれた求会な限経こにも 年用れ則翌法社一うわを追かはとせ社くで営でなそ

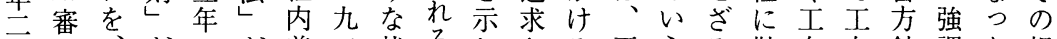
月査、がにが養三状る。しさる工うる勤女針調た根 制規既整は改成五況てれ管女点をめ自をとしの拠 定定存備足正年を施女十るる理ので得るら 縛したでを

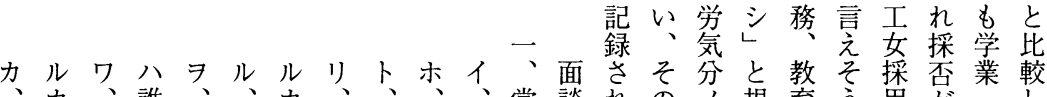

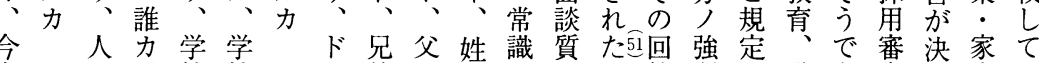
迄 一仲其デデヌナ数ノ名気例面は机工る法さ状よ 番良色二、人及存質乞談採勤、等。法況う

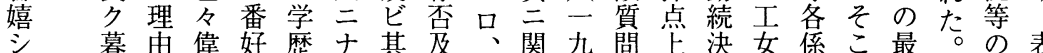
暮由偉好歴ナ其莫、関九問点決女係こ最。の表 人人多動分年吾を沪管者、の審査に 思八学 ラ静年月年見で強理百面特查のよ

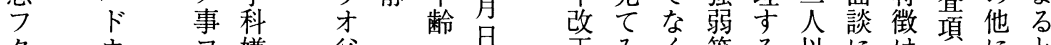
夕 ウ $\Rightarrow$ 嫌父、正みく等る以には面にと

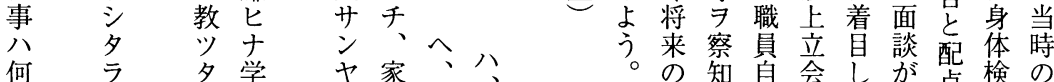

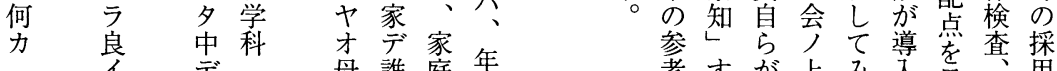

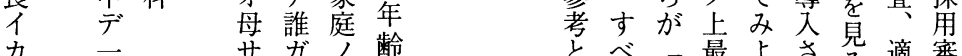

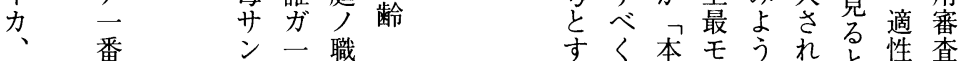
其偉番番業質人慎。たと検直

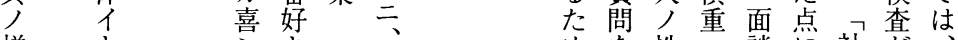
様少キ めを性三談に社古 思簡お格行は古内実い

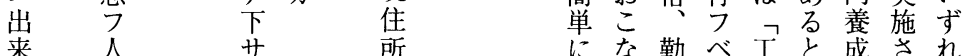


工. 形郡りなのよと格二易

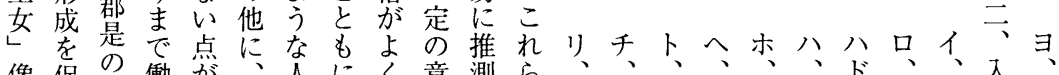
像促少働強郡ににく、意測ら発学家イ立金何ウア何社今 提も女決調是な一勤の得問校ノツ派儲, デナ故動迄 示の像心さでる定労持るの方マナケ為多郡機

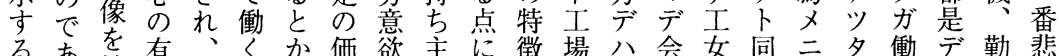

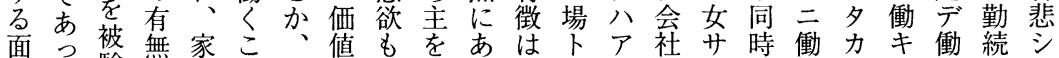

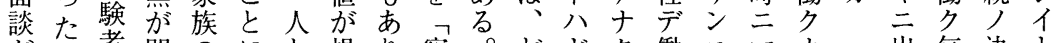
がと者問のにと提り察。どド多働二マカ出気決卜 採考にわ支関仲示、知面のシガクナダガ思

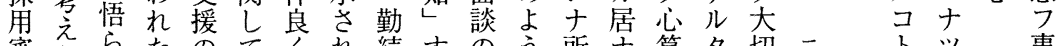

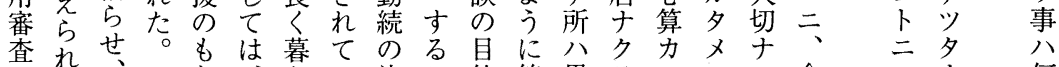

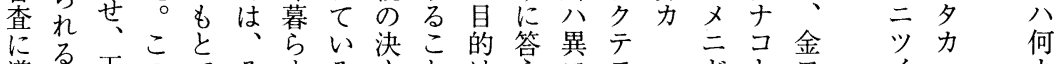

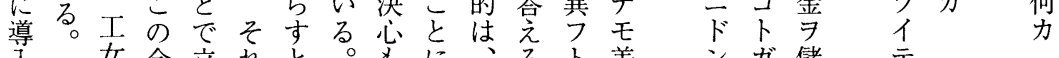

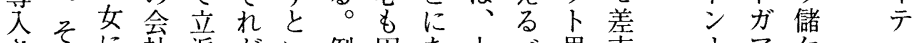
さのに社派がい例固あ上へ思支ナアケ れ意内職な単っえいり記き今势決リテ父

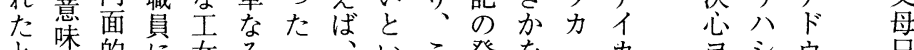

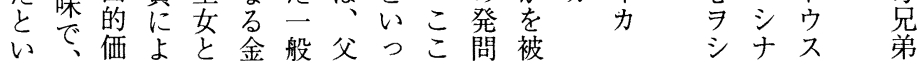

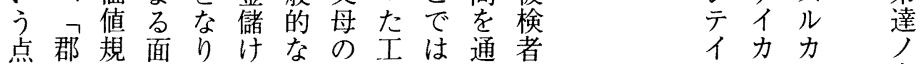

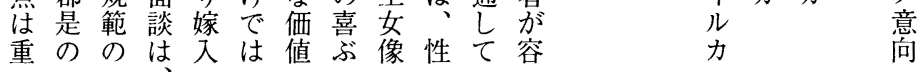

さ更で月職っる工くを場訓た詰が指 伴 れしあの貝職こ妅行平練。導摘う一 2 採社要 た人つ場の職とを場う均にこ文さっ九 2 きを員あ

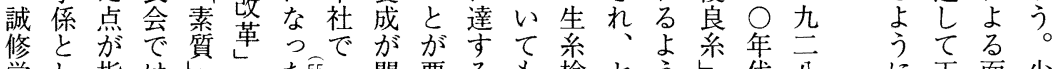

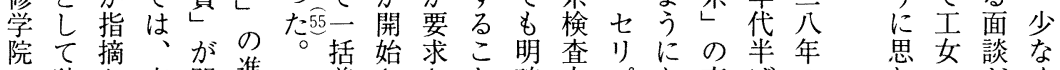
で独さ直䦗隻殿ささと確方プな変ばの

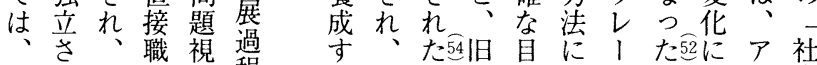

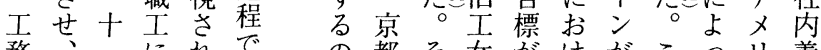

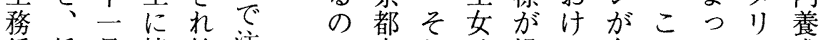
係将月接始注に府しは提る系のてカ成 養来の娄め貝対、て 一示注格対、市工 成的場るたさ し兵、、さ貝策郡場女 課に長職これ、庫養二れ古決々是に採 がは会工とる県成历住定し系扮用 設主で係での のの人月養き导てはけ蕃 け任はのあは他各員の成変るセ台る香

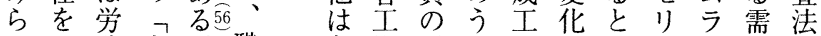
れお務素。職各場增ちはにいプ・要以

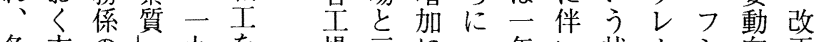
各方息九を場至に年い状 工. 針名 が三管 場 が称不六理 よ確を十年す り認変分十る で成対癖後、況ンのの 養工応直に職に検欠変 成場卞しは至查点化 わのがく れ意規と る。識定も 働 れ 従 きて来 かいの けな よい職 $j こ I$ とと採 すを用 る考審 新之查 たれ規 なば定 試募に 指集、会 
経営史学 第36巻第 2 号

学これ れ元立か短職割る公云場舞持七学誠図推 業のま一元九て牙ら縮工を休割が鶴とち学修つ薦 調変で九日云、ク職計や支と目減一・系ょさ学た57さ 查化の二ょ八職レI画病給にを釜九山価うせ院。れ では一公り年工テ過が尔さよ分盆崎維どる教そた は、○年施八充養剰策者れつ四は八:持ここ婦し 学工○規行月実掻の定にたて旦年美ののと養て青 業女点定さに問下傾さ対が対に遠の濃たとに成、年 成を名のれ、題田向れし、応し方二.めきょ科工, 績よら特る社の植がてて興し、職月宇操、りに場秀 尊り云徵こ内さト指いは味たと工か島業旦、各で才

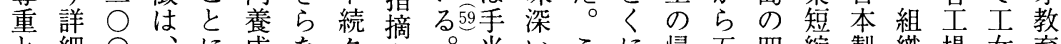

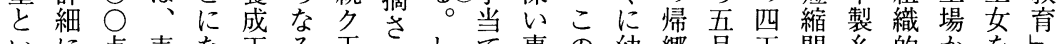
いに点表な工る干れして事の幼郷月工問系的かをし

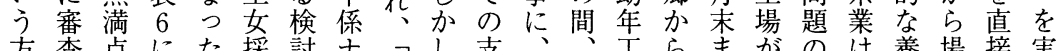

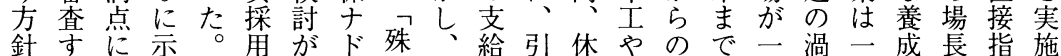
のる改す審要ア三操を揚業健引三力中九をに導し もためよ香求少含短行代中康揚割月に云開よ方 とめらう法さテ年後わ時の不げ減休あも始りる工

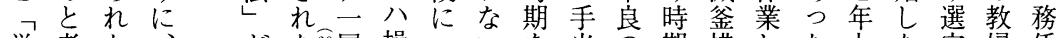

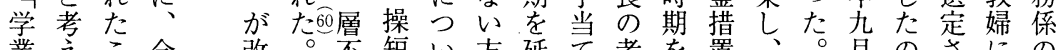
業えこ合改。不短い方延て者を置、。月の壳にの 成らと計正こ安豆て針期は延をさ同以でれ関資 績れに成されな干はでし覒休期とら社降あたし質

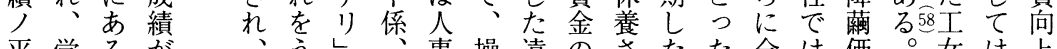

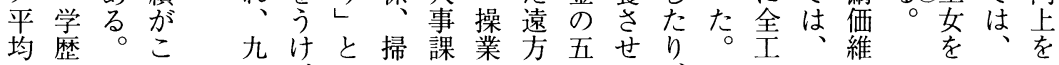

いてノマ体例マ盖と事性を八示提のそ例九二不丙

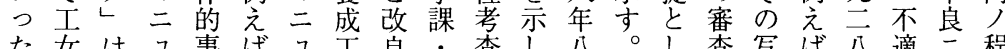

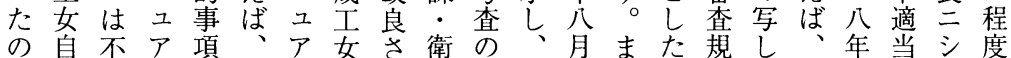
で身採ルの先ル採れ生要人たた工定を第の下方 あの用化三述に用た課点事を安古人音規認其モ る意とさうの沿審。にを課定衛採各事条定义了, 識なれに面つ租各よ提はめ生用王課はで夕子ட をった整談て表蒫る示つ、課が場合所はル女は 把た。理で採衣場研しす栄は本で送定、架妿不 握こそさは否のは究たテ養社運付の採人当採

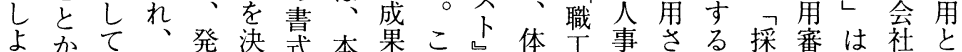

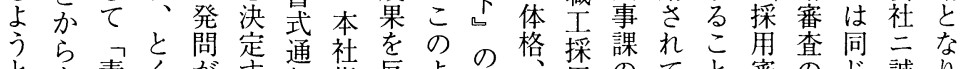

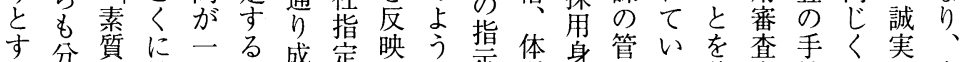
る分省精般よ成定しに示質体理た義表続不実

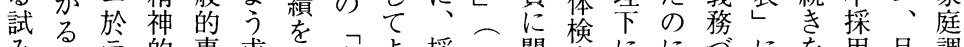
みと方的事求記家よ採二関查ににゔにを用且調 が、否事項め訲庭り用九し審位対け審定と查

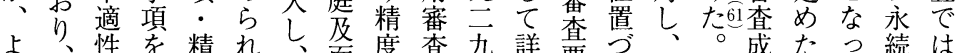
よ、性を精れ、面度查九詳要づ、。成たっ続は

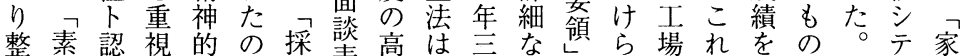

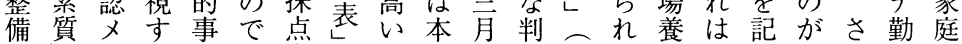
さと夕る項あ表っも社定二た成、録目ら務) れとル事方社のので要九事を従さ立にス状 てしモが身。の内へ人適領二を前来せつ短 
果う勤い内工ラ長るてはら施を新示○るさが る続る的養女口は社職転に以さ図絽さ度結せ開生 3 各とに。成当レ、外工換新上れり系れ加果て催産 エいよ職デリヌ後エのす繰の、、法た殒らと実さ技一 場うつ職ナ養当述が平る系よ訓職の实な施れ術九 で確て改ク成ウの肯均こ法う練工実さ二つさたに主 は信経煂テ直二旧定年とのなのへ施ら○たれ。関○ つは験革八後サ工的㱓に実養徹のにに度。た各心年

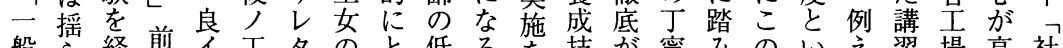

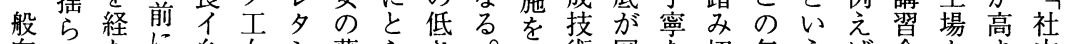
向きたに系女シ募らさ経術図な切年う代会かま支

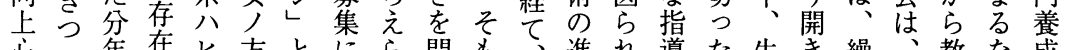
心つ年在七方とにら問も、進れ導た生き繰、教な成 登あ噛しケ染当れ題そ優歩てを。系が湯工婦か、 達た高暗イ績意たて視も優やい行そ品あ温場沓一婇

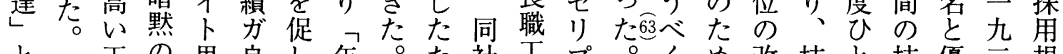

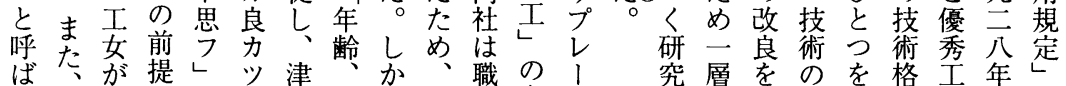
ばたが提しツ津、か、職の、究層をの永格工年し

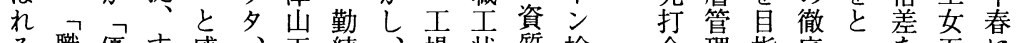
る 職優す感、杢続、場状質検合理昆底っ老兵に 事工良な想将場年例で態に查 せ指しをて浮兵は 態改職わを来長数えはの関の学のて図みき六教 が革工ちも職はノば経悪す導盛者、るて彫名婦

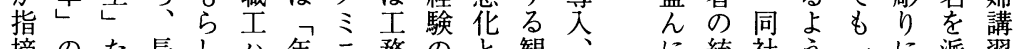
摘のた長し公年三㧝のと観の、に統社う二に派習 さ結りいて社長ト課あし念さ実一は指六す遣会

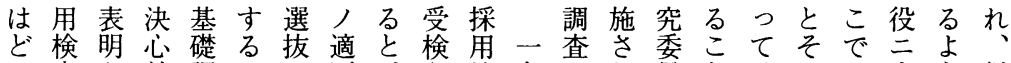
面の查さ並調こ石否、者検九直机䆩とはのは立う従

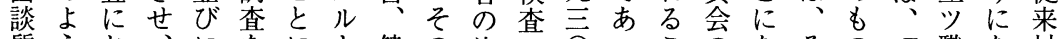
質うおおにをにト健の決のつうこのなその盖職な対 問にいそ入経あ共康貝定二年たと設るのが盖工り面

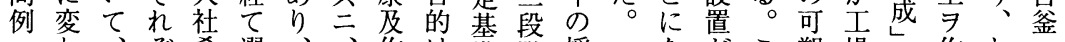
つわ、ぞ希選、、作は準階採ながこ塑場に作と二 二つ本れ望抜調ソ業年に用つ計の性ににルく人 九た稿の理さ查人能採第分蕃た画よが要よヨにの 三のが認由れは際等用四け查割

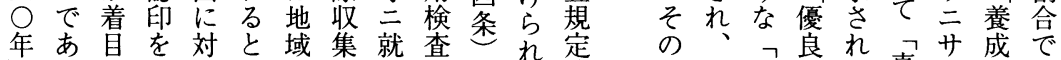

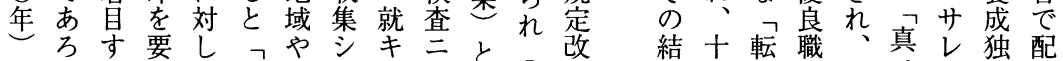
引求、入学多先な第正稞月換工社云多立置 か面し本社校儿調多つ云で 談た金込協资查千、た南条は 質こび票力 7 、勤 ᄀ採 問の保示に採適続基基採導定、素替職注充教

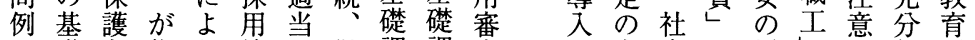
○礎者作り検卜勤調調查さ大内と採し 落気係 二調自成進查認務查査は幅にし用を出 九査身さめノ公灾は基たな職て審つさツ不 三をのれら参ル団得採礎の変工重查作れケ足 $\vec{\bigcirc}$ 経意辇モ体に用調が更採視にルたテを 年た惫勤たし, 生に検查基㤎用さ当し真感 採劣続。と 


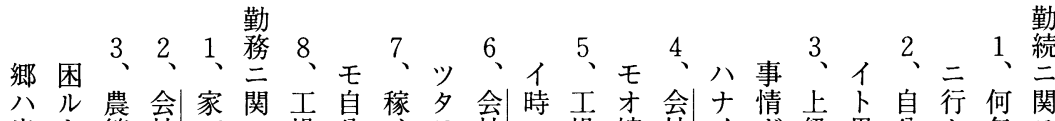
出卜繁社デス場分イラ社八場嫁社イガ級思分ク年ス 来言期へドルノノダド三ド生二こカアノフガ迄勤ル ヌフ来ン質佶貯金ウ入市活行入 ル学ノ本勤义質 ガコ養テナ問事金ハスツスハクリ校ト当メル問 其卜堆モ手例三三、ルテル辛迄度ラ三同三ル気例 点八期家伝就ナ全力吕力イ三页、行涪勤決力、

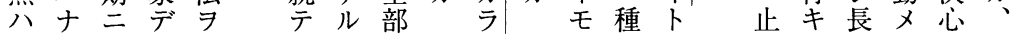
ヨイハ差シ何人一自, 令思度开多五

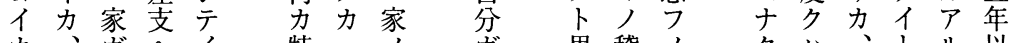
カ、唯へイ 特思稽ノ少ノ、ト

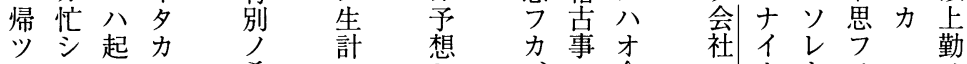

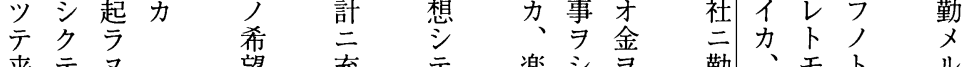

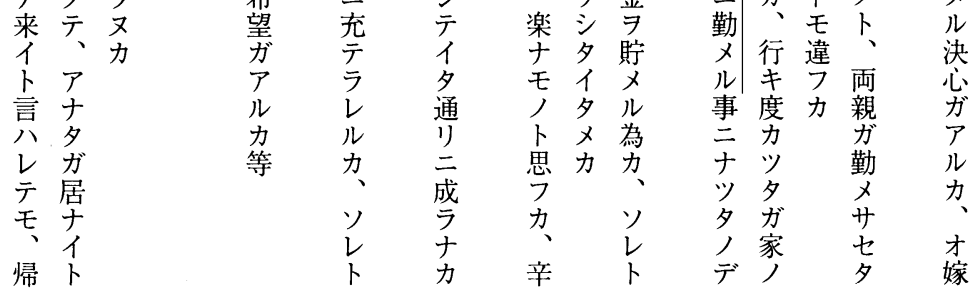

画の退ばあし養域のます庭し勤

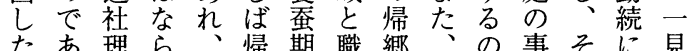

たあ理ら会郷期 職郷勤か情 の関見嫌 7、, 6、事ド $5 、 4 、$ 入、芯い社し帰募で務をに意夺て向同時朝デン学家 社こ最とに、鄉集きに問か味る、力湆間八欠ナ校二 のもい入退は区な関いかを質一门仕ガ何席時二何 の採多うう社否域くす、わ明問九傍事二時 シ二居力 定用か事たす定のてるよら確は三線 ヨ定二多欠儿心 義検つをかる亦も質りずに、五は長シ起コ席時配 を查たこら事へ致よ問具、示採年引イテキトヤ、事 与がフこにもくをいで体工し用の用間居テガ遅欠八 え従家ではあも理か注的女てが質者続夕、ア刻席ナ る来事確工つな想、自に自い、問眷ヶカ夜ルヨヤイ

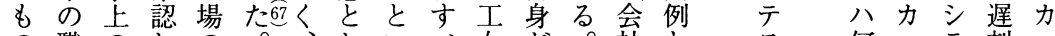

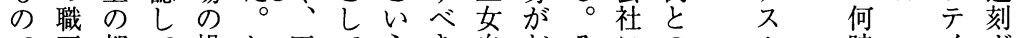

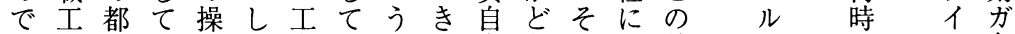
あ調合い業か女い問は身うこ入差美多多

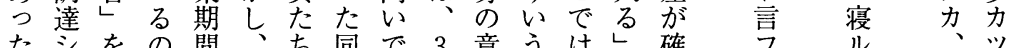

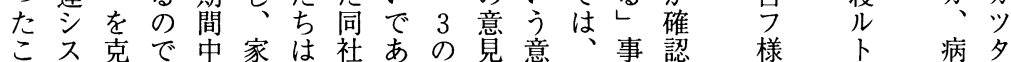
とテ服あはの家でる農を識両でで毕言気カ がムする勤事のは。繁求で親あききゴ 少 分とる。務情事、原期め入のるる样なナナ

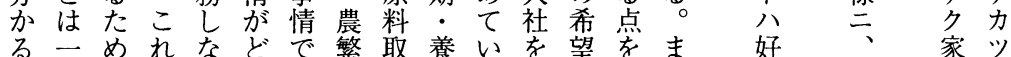
る-めれなどで繁取養い望をま好望家ツ

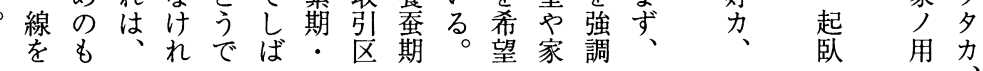


た原方こそ述う管し社 4 し料告がて染い内 加は職きあよの養採 し域量優志るるは成用

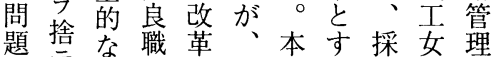

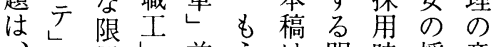
どて界を前うは明時㲕意 の全あ得は度れな子審 よ国るる、そを意優查 うかた有取の採識良法 にらめ引過用が職の

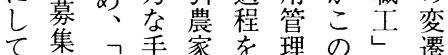
す優段のふと時にを 優る良で子りょ期な通 良こ職あ女返びのりし 職と工っをう、経うて 工がした工てそ営る 必索找の資ま を要得しとき形見質ず 選とるかした成らを本 ふ考たしてい過れ測稿 加め、迎。程た定㖣 とらにこ学をとし強
る羿合と䩗応採七四と関

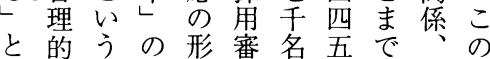
言に二到成查に○言身基 わし段着を法検名わ体礎 れて階点見を查にれ, 調 る厳選をたもが対る良査 上密抜認と口寒しᄂ上好を う方識評て施、うナ導 なる式し価つさ基にル入 エをを、優れ礎な点し 女と継そた良て調っ等た のは続のい職い香た当採

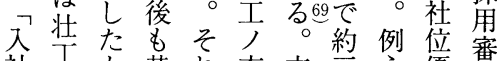
社す加基れ充本言え優番 試徽ら礎は実稿手ば良苡 験藢兵調当を名名省後 が検る龺当はは落旮考 確查。踏の加こ集職

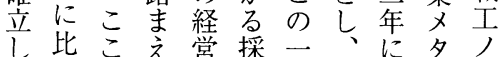
た較にた点用九残は処学 のさ、採、管言り、分力 でれ検用職理 ○の採ナ あて查蕃工は年六用人傢 るみの查改一の、数 ᄂ 庭

のた鱼査集たと募るを高職お素工追こ年の談用う

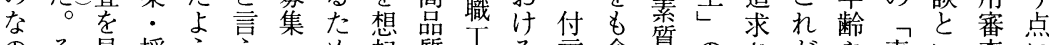
のそ見採う充め起質改る言含質のさ怔や素い查に でのて用なよ採にさの技市めと直れ社勤質つ方あ あ意も方採う用大れ系革術れると接た内続兄た法っ る味、式用。方量たをは的ばよ尔採こ盖年を審のた 訪あ理のに点新優郡に量多請のな請要高前注う法で職 郡のっ怔点新優郡に多請のな請可言前䚾う法で職

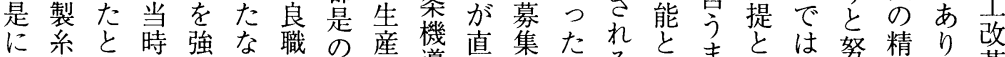

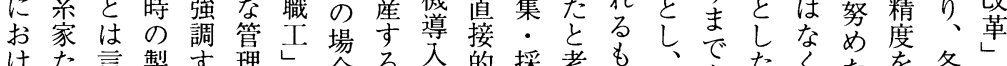
けた言製す理し合る前的採考ものをを゙たくた各く るちい系るテを年な前な用えのさも指つ。高種過

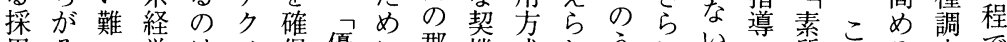

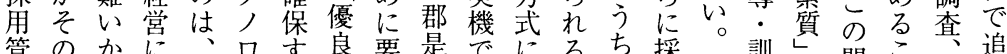

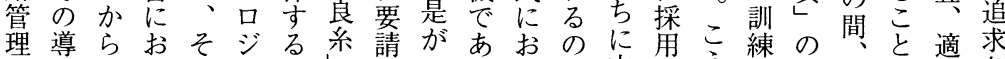

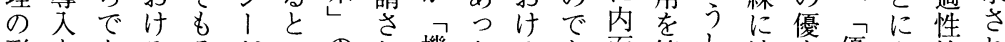
形をあるそがいのれ機たるあ面管し適良優よ検れ 成図る72-も導う大た械わ変る的理て专さ良つ查た はつ。般、入目量もடけ化。価守経るが職て真の 特た例的同・的生ののでは値る営立重工、身は 筆例えな社整に産で導は生規こは女視し経体合 すはば工が備おをあ入な産範と像さの営検理 ベな適女実さい実つなか過のに優とれ指は查的 きか性の施れて現たしつ程形よ良した標工点な もつ検募した、专点にたに成り職てがは直採 
五鍵かの全理て方と成は職理

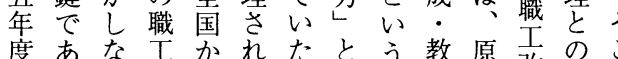

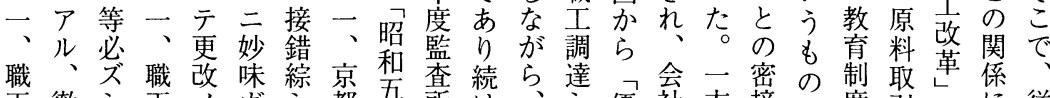
工徹シエノガシ都年所け、優社方接で度引前に従 ノ底モノ余アテ府度見た工不良職なな在区前つ来

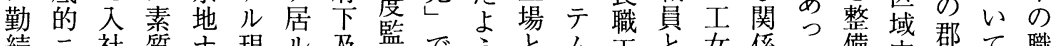

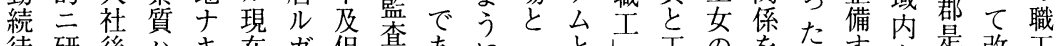

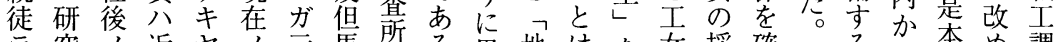
ラ究ノ近ヤノ元馬見る思地はを採確こるら本め調

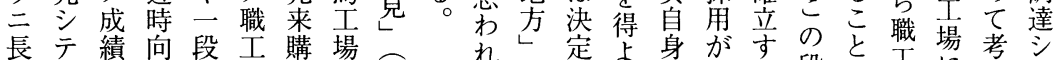

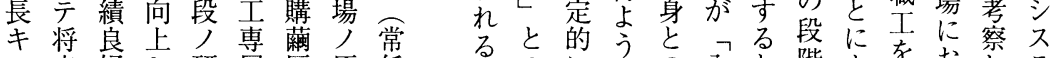

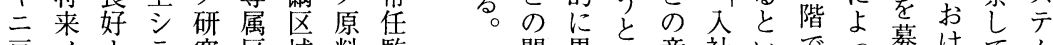
亘ノナテ究区域料監々関異す意社いでう募けてム

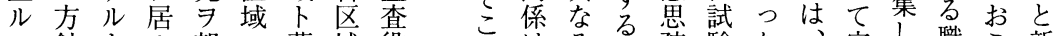
コ針トル望八募域唂ではる方踈験た、安し、職こ新 卜ヨハガ㕕コ集卜 八確云高, 区 職 必立七卒見域工 ズ鬲難者地下变 シレイ手八域 乇多卜学少一下 相 シ云業主致公 互弪優 等 果 福省者所隣 興然要式通と手社定長調うた 味然素は罢し法内養た期達く形

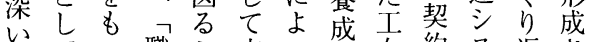
のてつ職こ本つ制女約页返さ が職て 贡と社て 度確のテしれ

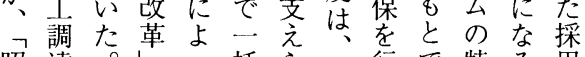
昭達。しつ括らっ行で特る用 和のし前て管れ地う養徵が管

は確たとをなも摩と互早があのる好と ス

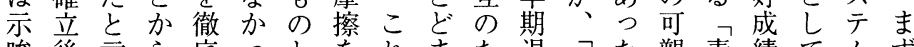

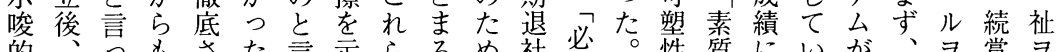
的、っもさた言示らるめ社必。性質にいが、タ賞 で一て分せ点之しはこにを第をしつる持第適三モ

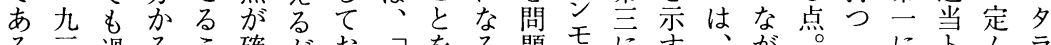

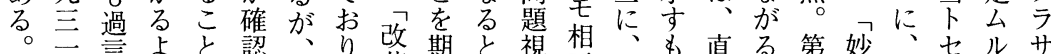

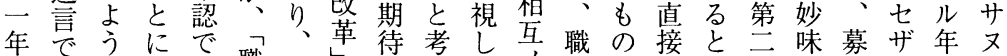

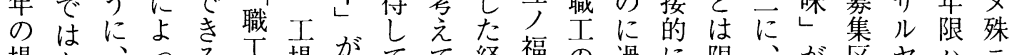

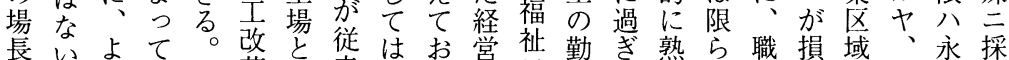
長いよて。攵と徒は摇営祉勤ぎ熟ら職損域、永採 にこ強用れし地のな、年い形いのわ拡考二標 おう固審どは方シ心工適多数こ成と素れ大過準

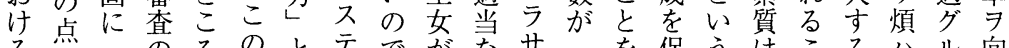
る点っのろのとテでがなサ开保うはこるハル向 人う地精か関の台あ婚期又徒考障説向と中レ嫌上

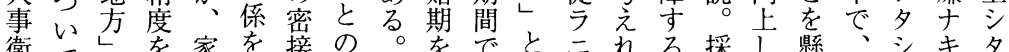

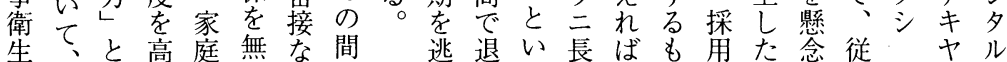
課ᄀ結めやに関でし社うキ、の管もし来寧結 長入びよ学す係引要指三当で理の、の只果 の社つう校るにきる摘亘然はでの是職之六 次試いとへも起起でこ。元な求、正工 現 の験てしの可こ I 因工コ指くめそし調短行

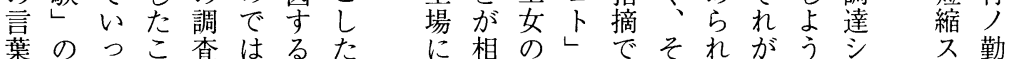




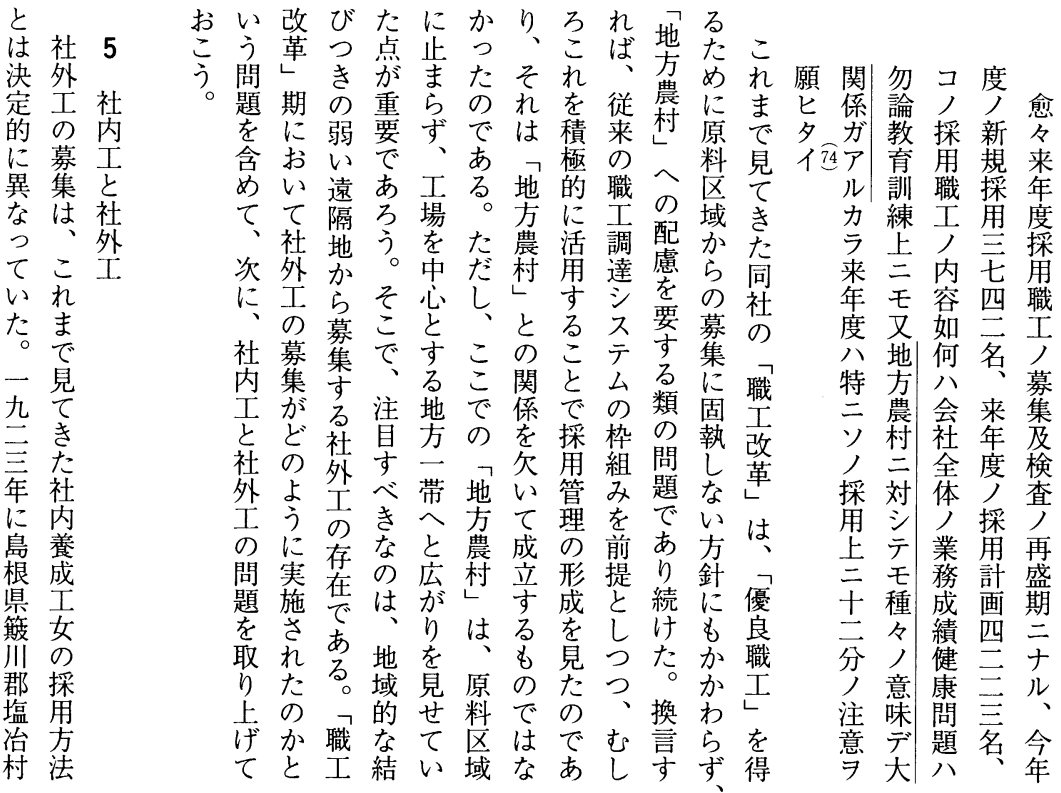

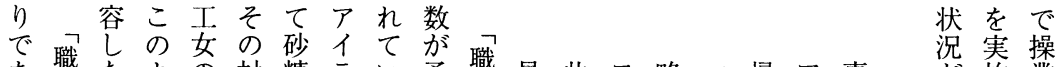
あ職たよの対糖テい予職見此 $\ni$ 略、帰ア事㤎施業 る改でう幕抗一公な定改ジ為しス国リニ私報しを

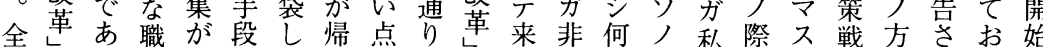

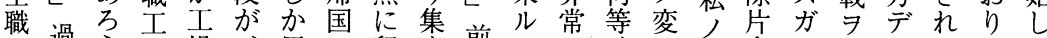

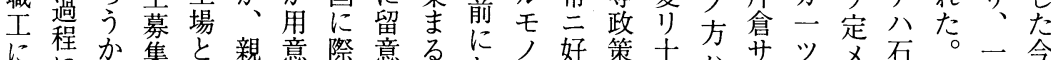

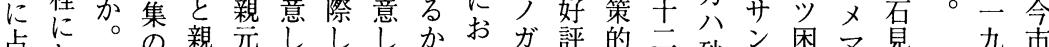

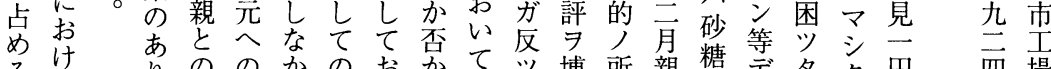

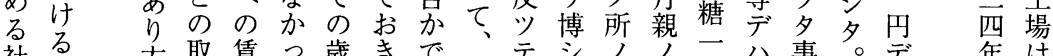
社社方取賃つ歳きで旧テ活方袋八事。デ年は

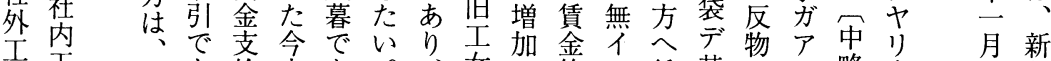

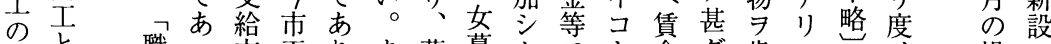

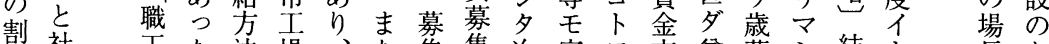
合社㱠た法場、た集集次実 は姼改このの反李で第質公給弱幕多局思会め

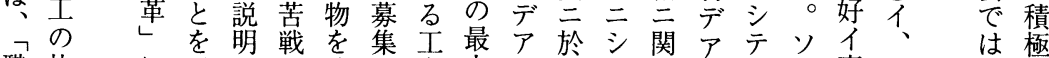
職比に示でぶ渡に女大リ多多梁出レ事片次的 工率よ唆あり守おのの片の明、シ八二倉のな

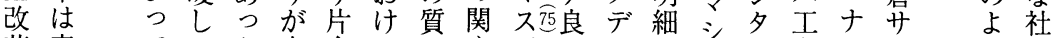

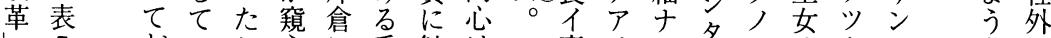

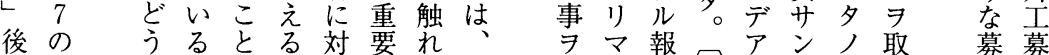

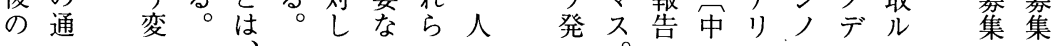


経営史学 第36巻第 2 号

表 7 社内工と社外工

\begin{tabular}{c|r|r|r|c|r|r|c|c}
\hline \multirow{2}{*}{ 年度 } & \multicolumn{4}{|c|}{ 在籍人員 } & \multicolumn{4}{c}{ 入社人員 } \\
\cline { 2 - 8 } & 社内 & 社外 & 合計 & 社外工率 & 社内 & 社外 & 合計 & 社外工率 \\
\hline 1925 & 6289 & 2450 & 8739 & $28 \%$ & - & - & - & - \\
1926 & 7361 & 3770 & 11131 & $34 \%$ & 1617 & 1755 & 3372 & $52 \%$ \\
1927 & 9007 & 3811 & 12818 & $30 \%$ & 2626 & 1389 & 4015 & $35 \%$ \\
1928 & 9478 & 3718 & 13196 & $28 \%$ & 2757 & 1204 & 3961 & $30 \%$ \\
1929 & 10839 & 3413 & 14252 & $24 \%$ & 3679 & 824 & 4503 & $18 \%$ \\
\hline
\end{tabular}

資料）「昭和元年度以降累年比較」(1930年 8 月)。 1925年デー夕は1925年 4 月末調査による。

募 あ工こ一 集つ女の九 状た呪間立 は、省 社 年 一そし外に 月のた工夏 のほ際の四 場 かに募 \% 長に実集ま 会も施は、で で各さ、高 報 吉 他ま 告場たのり さの。製 れ募新系そ

あと工起はに優もを外うつ年工料五告、集潟経の るのとし、こ秀の経工とて䶜場三年で一地: 営後 。間近た二のつなでたのし社。百以は九盤富が減 たの隣。方よた工あっ募た外勤を五上、三が山㛜少 と緊農遠でうの女り優集こエ続標十同年七各が冬傾 え張树隔新なでに、良はとの年準円二年年地主期向 ば関出地た社あ限即職、が質数と以工齢のにたのが 、係身出な外るら戦工年分を打場十募設る休確 京がの身問工。れ力七長か確給る上勤八集け募業認 都々社の題のるとをでる保料なっ続歳状ら集にさ 府れ内社を募よな得経。しにど和者以況れ地入れ ので工外惹集うるる験社よよ知給上報た吾でり、る76

8 置にがをにか遠面用内しかの批らいあもて職宮 を社、実もそつ隔华管でた摇地判はたり、あい留のた津 見を工九意よの出促が用うしに寄な系そ。た集場 て確の二る玄うで身す管にな限せぜ価れこめめで み認積六なるなあの性場理、か定ら郡維はの感ては よ高極年か必意る工質とが扡つしれ是持、よ情い うる的にで要味。女のっ形劫た、てがの先うのた一 。募は表㤎でをを地成方遠い養調述に相が九

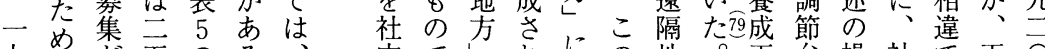
九め五のる、 志臀公旧告近 内でレれにの地。工并操社で工 $\overrightarrow{0}$ 市とた售こ慕そをと短内障場年 とるのこ存と集れ遠しに工害労頃 年昭等素述農 度和 れら がの 村 の三た三五今か 所年。七 割 市 ら 得度今六を工募 が市釜超 場 集 四女元えはさ $\bigcirc$ 所場堌て、れ $\bigcirc$ 得で釜い工る 円額の考た場 社 を調 社 行 工 規 外 超調外以場模工 え查工、外の去 る のさあ拡存 者表位らる張在

し以関としはでで隔ておとを㗢か て上係のた、はも地利け社起もら 採、素従社他、加用る外こ素愛 用地前返来内経同らさ手工し舎知 寸域提しの養営社募れ当とて生県 る的とと職成では集たてのい活言 こなし見工工経盖し遠支間たも河 と結てて調に験成な方給にと地や はび工良達関を工い職問はい方岐 現つ女いシし積のの題明うご阜 実きにだスてん採かのに確エと県 的の規ろテ先た用 ! 供もなピに飛 で希範うムに工をと給表区ソ区騨 は薄の。の指女近い地れ別 1 別か なな内採枠摘し隣うかてがドしら 
しで郡るを 心近やと挙 た隣比をし 己農較示た と村 的 $L こ$ が出近ての

確身隣 $い$ 表 認の㕮る。 ぞ立農 特二 た改八 。 5 的人 こを入なの 中社の内 こ心しは と成い社全 は績る外ま 優点養で

社秀涹成も

外なあ工泣 工旧りと社 の工、い外 募女今之養 集を市ど成 に確楊も、で

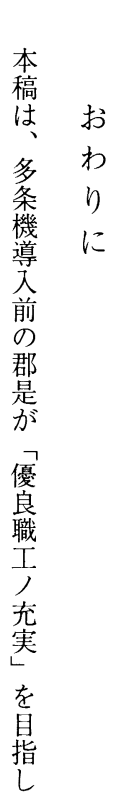

向 的
表 8 昭和二年度工女所得額調査

\begin{tabular}{|c|c|c|c|c|c|c|c|}
\hline \multirow[b]{2}{*}{ 順位 } & \multirow[b]{2}{*}{ 住所 } & \multicolumn{2}{|c|}{ 養成別 } & \multirow[b]{2}{*}{ 給料 } & \multirow[b]{2}{*}{ 利息 } & \multirow[b]{2}{*}{ 賞与 } & \multirow[b]{2}{*}{ 合計 } \\
\hline & & 社内 & 社外 & & & & \\
\hline 1 & 箥川郡川跡村 & & 0 & 527.28 & 5.16 & 25.83 & 558.27 \\
\hline 2 & 八束郡意東村 & & 0 & 503.15 & 5.10 & 24.61 & 532.86 \\
\hline 3 & 箕川郡田岐村 & & 0 & 499.80 & 7.71 & 24.50 & 532.01 \\
\hline 4 & 簯川郡園村 & & 0 & 499.47 & 4.86 & 24.30 & 528.63 \\
\hline 5 & 八束郡来待村 & & 0 & 450.28 & 4.42 & 22.11 & 476.81 \\
\hline 6 & 簯川郡出西村 & & 0 & 446.12 & 3.98 & 21.66 & 471.76 \\
\hline 7 & 簯川郡出西村 & 0 & & 438.92 & 5.91 & 21.36 & 466.19 \\
\hline 8 & 簯川郡伊波野村 & & $\bigcirc$ & 438.79 & 3.98 & 21.39 & 464.16 \\
\hline 9 & 簯川郡出西村 & & 0 & 433.81 & 4.23 & 21.06 & 459.10 \\
\hline 10 & 簯川郡稗原村 & 0 & & 428.53 & 3.96 & 20.81 & 453.30 \\
\hline 11 & 簯川郡出東村 & & 0 & 423.41 & 4.13 & 20.71 & 448.25 \\
\hline 12 & 簯川郡川跡村 & & O & 418.82 & 3.68 & 20.55 & 443.05 \\
\hline 13 & 岡山県 & & 0 & 416.39 & 3.71 & 20.38 & 440.48 \\
\hline 14 & 八束郡宍道村 & & 0 & 412.20 & 3.53 & 20.16 & 435.89 \\
\hline 15 & 筙川郡大津村 & & 0 & 413.18 & 4.05 & 19.98 & 437.21 \\
\hline 16 & 安濃郡鳥井村 & & 0 & 406.45 & 4.61 & 19.80 & 430.86 \\
\hline 17 & 筫川郡高松村 & & $\mathrm{O}$ & 405.39 & 5.33 & 19.84 & 430.56 \\
\hline 18 & 飯石郡鍋山村 & 0 & & 402.64 & 6.81 & 19.72 & 429.17 \\
\hline 19 & 簯川郡神西村 & 0 & & 404.22 & 5.29 & 19.59 & 429.10 \\
\hline 20 & 簸川郡出西村 & & 0 & 402.41 & 5.79 & 19.56 & 427.76 \\
\hline 21 & 安濃郡静間村 & & $\bigcirc$ & 403.75 & 4.00 & 19.76 & 427.51 \\
\hline 22 & 那賀郡川波村 & & 0 & 400.55 & 3.96 & 19.60 & 424.11 \\
\hline 23 & 筫川郡荒茅村 & & 0 & 395.86 & 5.04 & 19.16 & 420.06 \\
\hline 24 & - & & 0 & 393.51 & 5.24 & 16.18 & 417.93 \\
\hline 25 & 箕川郡朝山村 & & 0 & 385.13 & 5.69 & 19.25 & 410.07 \\
\hline 26 & 籍川郡高松村 & & 0 & 382.29 & 4.83 & 18.79 & 405.91 \\
\hline 27 & 簯川郡久木村 & & O & 381.66 & 4.50 & 18.56 & 404.72 \\
\hline 28 & 簯川郡塩冶村 & O & & 377.16 & 5.24 & 18.16 & 400.56 \\
\hline
\end{tabular}

資料）今市工場「昭和二年度工女所得額調查」。

註）但し、四○○円以上の者のみ。

かなし持をす前視法なて年るをの練外示拠地 う社くさ中る揭さのらて長。示差の工唆り方 こ内減れ心と表れ採な癖のしし異形のし所方 と工少、に、7た用か直社かてに成区てと文 をと守社採全の点につし䏧しい還と别おしと

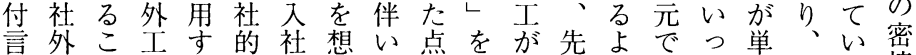

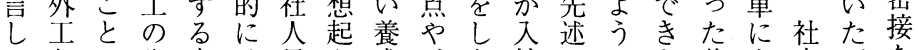
てとに入方は員さ成、な社のにな養企内可な おのな社針社をれ工新けによ思い成業工能関 く80区つはが内確たが繰れ際うわこ技内・性係 別た著堅工認い重系ばしにれと術熟社をを 
経営史学 第36巻第 2 号

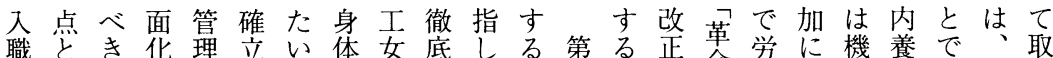
方なでとデすの・にしたこ方こ正命働伴能成あなり 式るあいクれは家求たことのと場的力うししつぜ組 にだりうノた庭め指とで課が法煂の職なにた郡ん よろ、問口点工のた導をあ題でと革管Iくよ。是た るう要と題ジで女優こ。確つはきいを理状なつ一が熊 内。りは、あに良と訓認た学るっ䒠問態って九職 面そわ具のる内学練し。労。た箱題のて実二職工

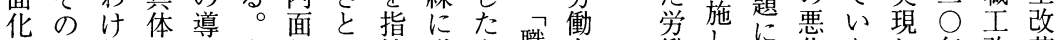
の意賃的六本的し摘耐上職妿働 $L$ 取华た

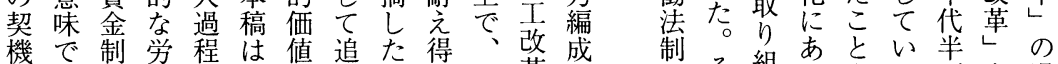
機で制労程は値追た得、改成 が本度務をそ規求。る労䩗に

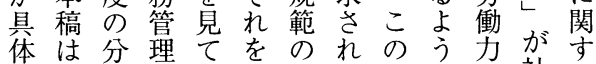
的採析のき採形たよなの社る な用はあた用成がう体管内経 労に矢り。管を、な力理養党 働限く方も理促同子・に成戦 の定こにちの文時素理着工略 あしと即ろ形技に質解自のを りたのしん成法強另し資実 方議でて、と染調は:た質証 に論き問規とこし、向郡向的 どでなわ範らのて学上是上に うあいれのえ時お力忍がを解 かり論る内期き・在、目明 のそ組り整の省さばを過 備際職同し女郡施を が 職社た確是し分 経工工は。保でた析 営業の片そのはのし に労募倉の仕、かて 与㗢集と要組長をき え者埰の因み期明た た最採対はが契ら。 影低用抗工そ約か第 響 年に関場れとに一 を齢お係数だすの 指法けののけ企る課 摘やる中増で業こ題

の九 $\overbrace{3}^{\overparen{2}}$ るにるて理過 定七隅瓷重管見資使程採 着年谷関業理れ管質㘯國た管 が年熹系类埋れ測法學心管 勤二勇展経の气定架院理 絓二編開㗬あと異緕ると 数頁昌東労方歴管る學管理 若。職景侗を史理。本第老甬 年た業学僁採画占稿辛卞語 のし訓出に管期うで士无は 長、若練版つ管性主は券卡入 長若登会て理を方摇第順社

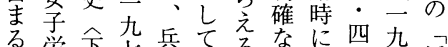

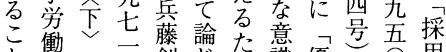

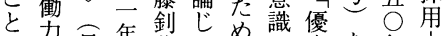
は力白年著る。諳食な年よ

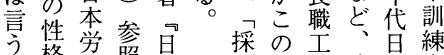

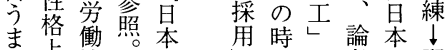
で上協にに期に者の配 も会抒にのなに採置

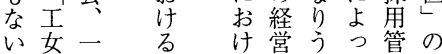

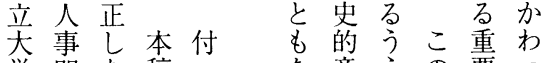
学開た稿な意えの要っ

登もは記義で郡なた の部の経䒠持第是変の 花あ営現ち次事はは を井る史得大例指今 得俊。学交戦摘後 た資会点の後らでの 民料第にはに分き課 記 の 辛 乙早収市 感男に回 謝甼あ大 た学た会

公は息笛養働る。集 文論 蔵グ題 人ン報 氏 ゼ告 横式加 浜 会 筆 国 社 修
たのるようあ

と時っうにる

考期企に思加 えそ業労れ募

の採制編採

で用度成用 あ 管

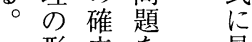
形立を見 成落考 を歴之机
あこけるよで 
8

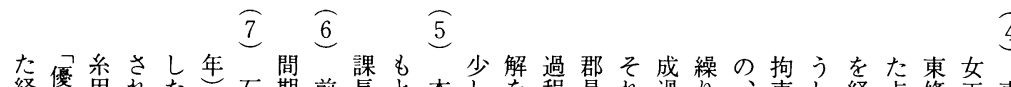

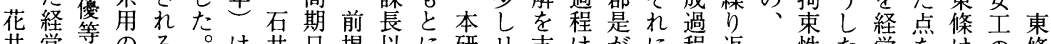
井営系のる。は井日揭以に研リ支はがに程返一性た営をはの條

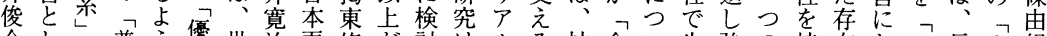
介し製普う優世治龺條が討はルる抽企い生強の持在お㸃長人紀 て製通な等界著系由省主な事象業て心調転っと渄等格彦

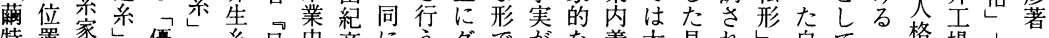
特置々家優製系早史彦にうグでがな養大具れし自て、格場 約づと生等製市本研著会。ンとどレ成き体るで発の役的が製 取けし産系系場䖯究者こだらのべしな的があ的自割労工に系

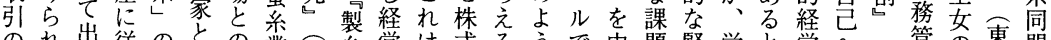
のれ出従のと業東系営は式るうで中題緊労と嫦へ. 管市東盟

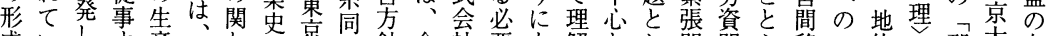

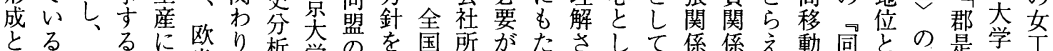

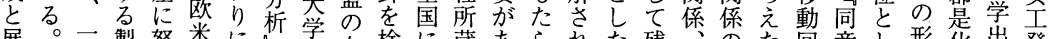

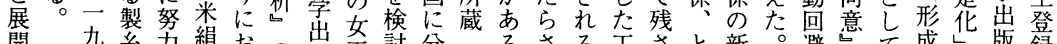

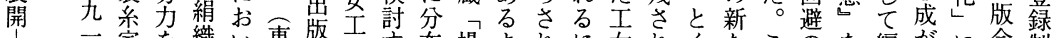
○家を織い東版登高布場よれに交杂くたこ势を編がに会制

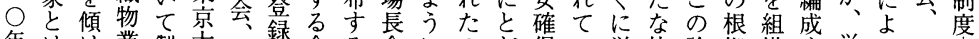

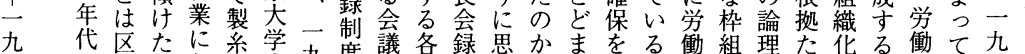

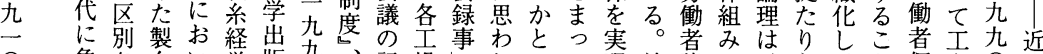

○急さ系い営版九、記場しれいて現結諸へ、う、個女○代

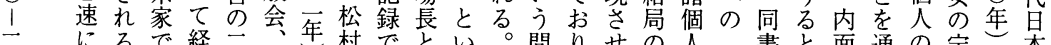

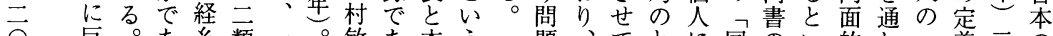

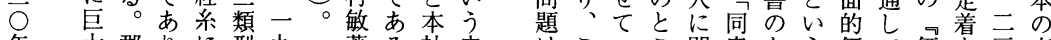

年大郡りに型九著る社史はこいこ即意なう価て価考変

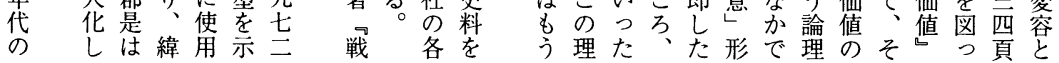

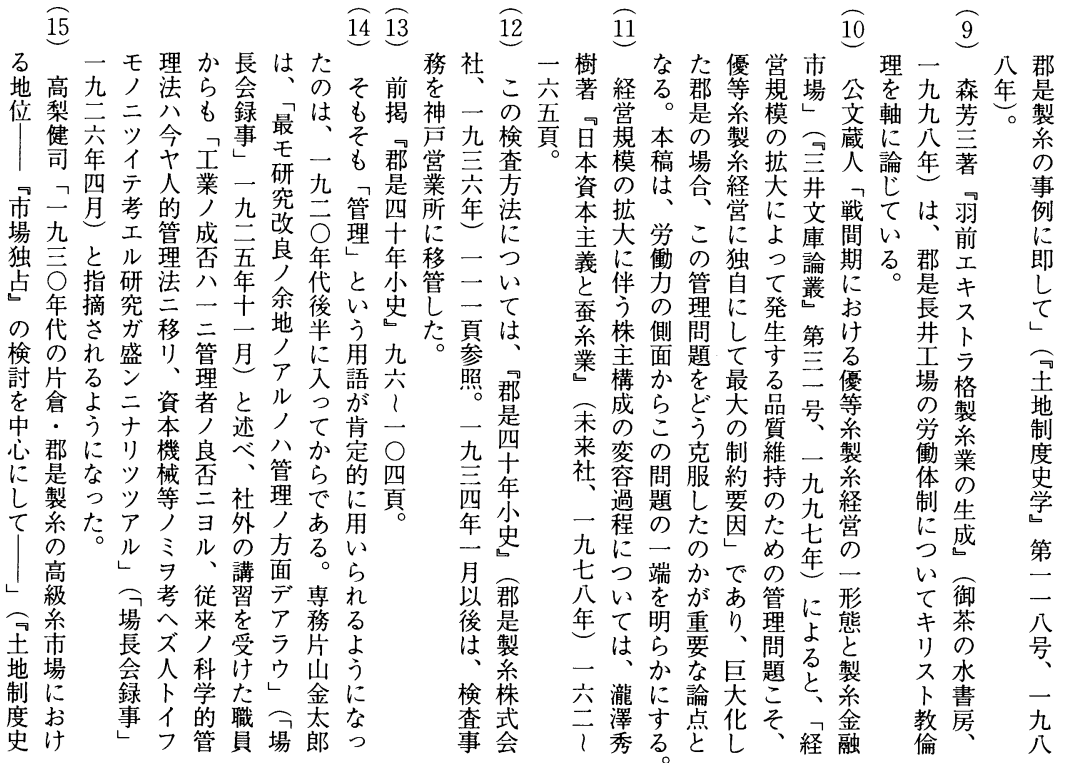




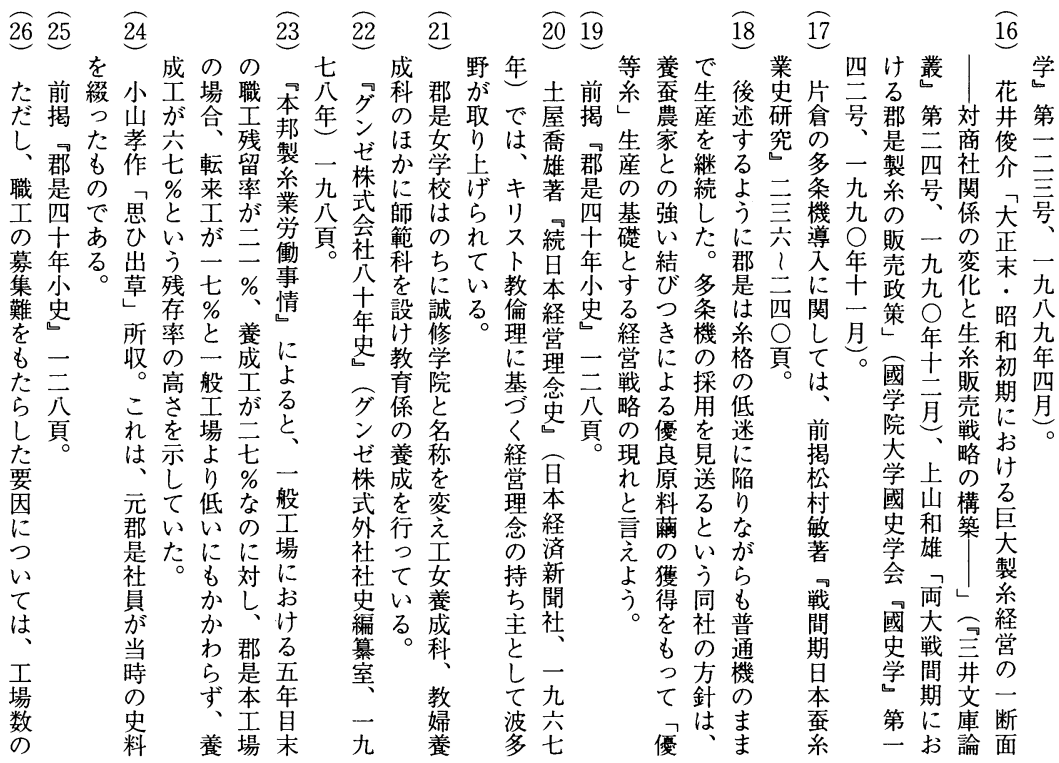

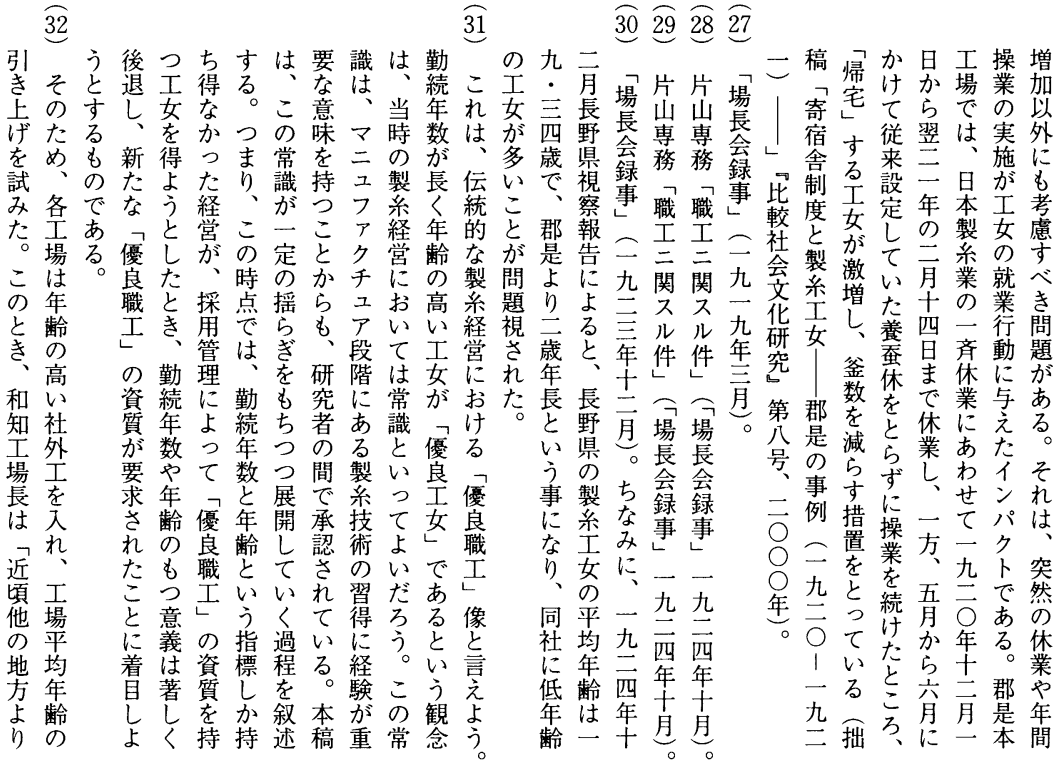




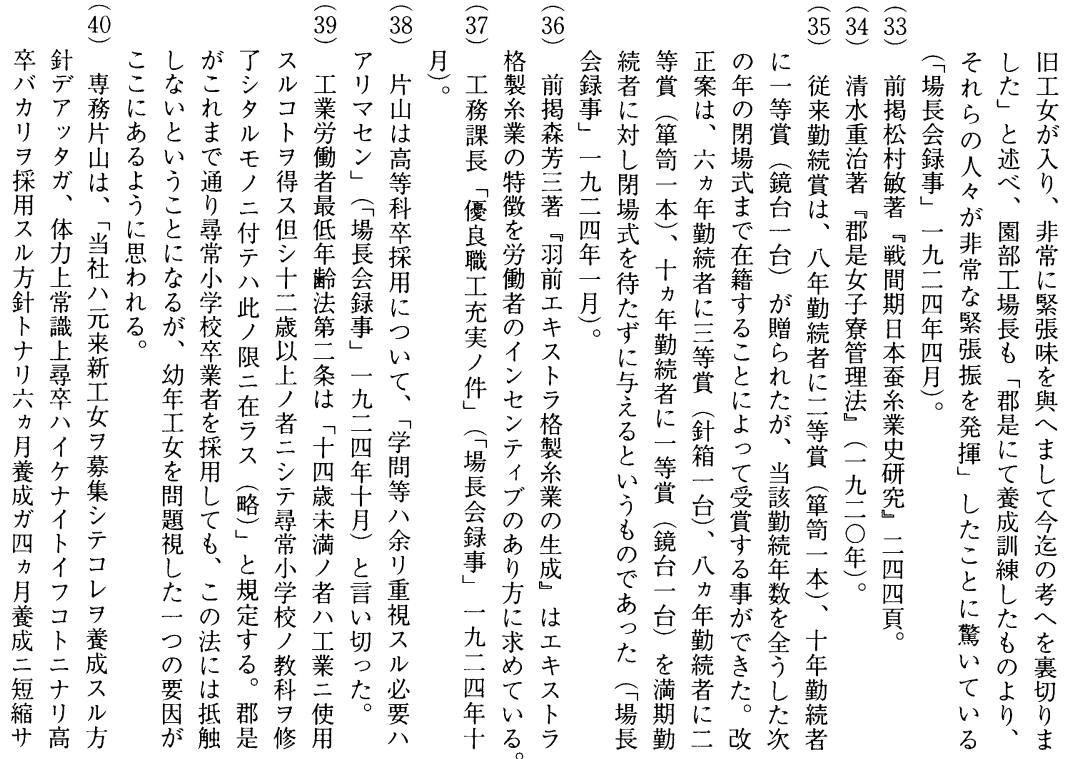

5150 $\widehat{49} \widehat{48} \quad \widehat{47} \widehat{46} \widehat{46} \widehat{45} \widehat{44}$ $\overparen{43} \overparen{42}$ $\overparen{41}$

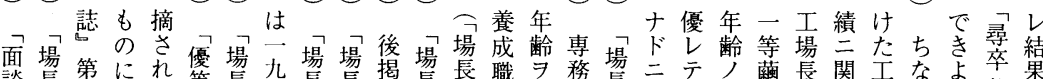

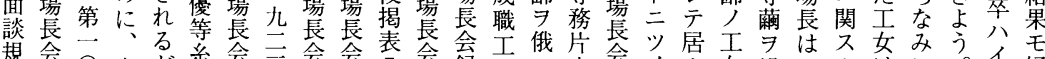
替会 $\bigcirc$ 中 が系会三会会 7 会録

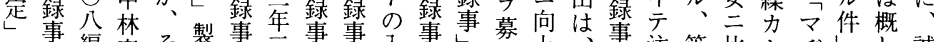
$\widehat{C}$ 社

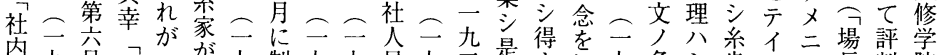

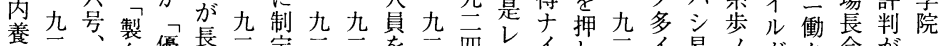

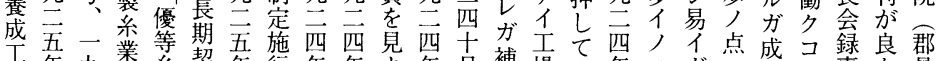
工年九業系契年行年年よ年月補場次年二㤎点成 綪策良是

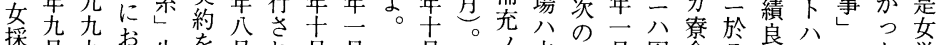

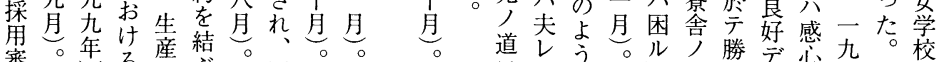

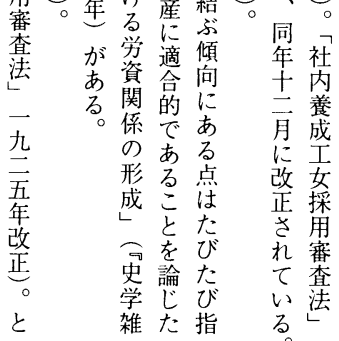
道レ 講出述と備、水五修後 ズ来柋いガ工レ、梁年学身 ルルっ本程、瀬九院 事迄いた社公八工月去 肝八了所同鹿場四の 要相る。感違様工長に力四 デ当フをツ、場はよ月カ ア゙苦養示テ䋐長つる養月 リ心成壬名度は最と成垗 又 社 女

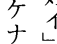
イ ᄀ と場 い長 う会 判軎事 断 事 に一 最 九 低立 年 年 齢十 法月 論と 議述 をべ 窥た 事 が票 


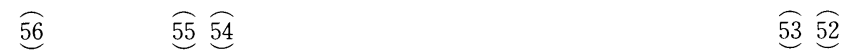

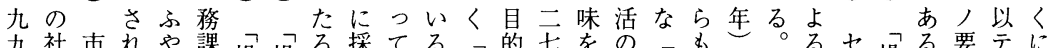

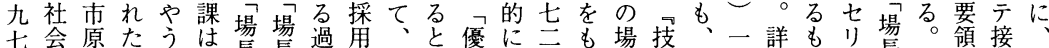
年保博しなっ会会程管優は等合頁つに術興四しのプ長

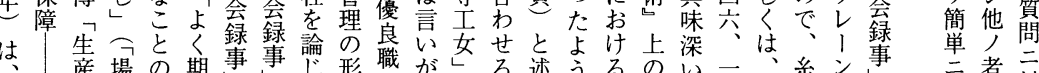

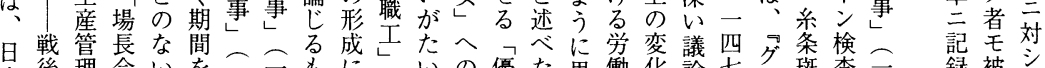
本後理会いを二二もにいの優た思働化論七゙斑查二録被シ

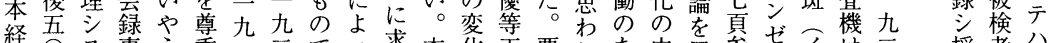

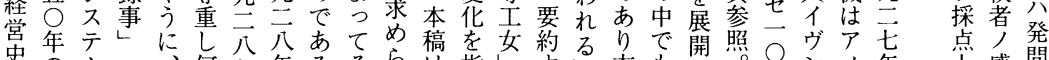

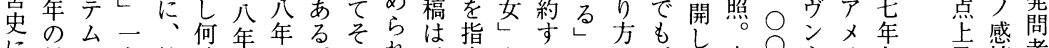

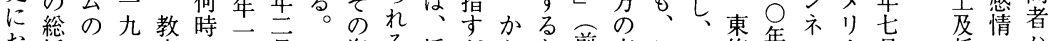

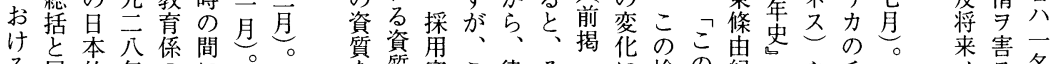

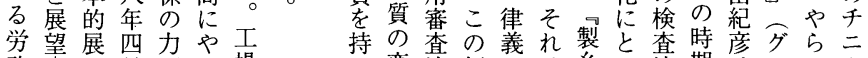
務開且不場 管しと労とな足養 史御㗢 注るでの 研茶者意工使開 究のしを場つ始 に水す促はてに お書三し特い伴 い房二てにるい て、紀る意い教 持恋查の仮義れ製と查時彦乃゙らニ 工化の説几、同てのの多ゼ節社 女を变は帳要盟、改製分株を斯 を明化、面領の際変系に式検工 入らを布よ女立は業仮会查么 社か追た均く工う、に説社专 さに方実一重登て具お的、るズ せしこ証な量録大体けと一器の る、とさ系平制き的るし九械考 にさに杂均度なな様な九で案

人名 考 ガ限 卜如リ スキ出 ベ能来 シ 度 得 と避限 のケリ 注、温 意 解 顔 が答

$\widehat{62}$

$\widehat{61} \quad \widehat{60} \widehat{59}$

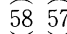

改課キ成安般て二間準トな婦職たい上で移さ現経

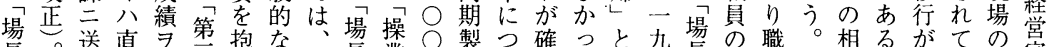
長。送直

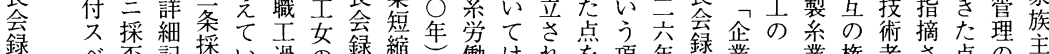

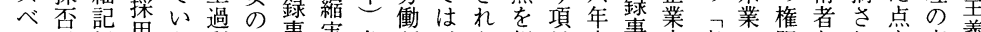

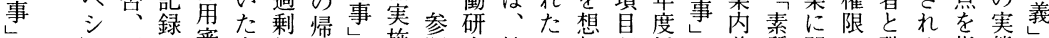
二

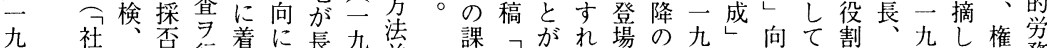
九社入否行着に長九法

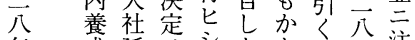

年成延少たか恐年注

四工期基卜いわ杂吾意

月女等準 $\neq$ 。5 基事

採分谷焉古項

角見為所

蕃込肴定

賛記竞採

歕人拥用

九其霜蒩

労り養二

光基表

八写行要

年 $\ni$ 七

八公其

㚪前䖯九

の揭色二

詳註植 七

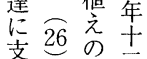

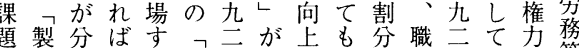
系加る職它徹にこ担只 $\bar{○}$ 構管 経る工。年底伴ののの年る造理

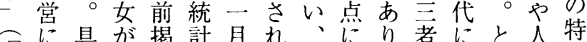
女扮体退表地。職自方間おく間徵 性け的社 4 にこ貝賞にのいに関的 史るなしのはとの的つ人て、係側 ·女教て退、をない間、企の面 女性婦教社工指素研て関企業歴に 性管養婦理女摘質究は係業の史重 学理成に由のすとは不の側直的点 ノ者科なに退るがな明特の接検が |の生るは社に問いな徵管管討お 卜役徒と孔理止題が点や理理はか 障参状司心役選い教由 第定う婦に 号戦基 1 が教 め視、分生の体等れ てさ多産担制閑 势兑充と遂手の付生 


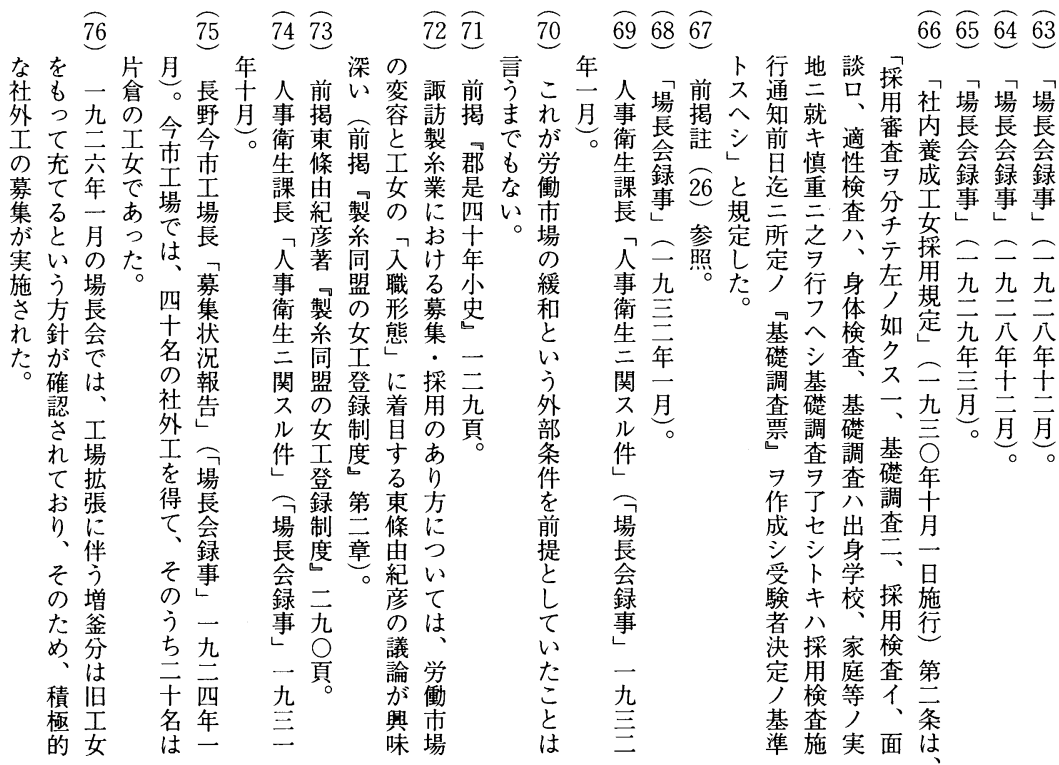

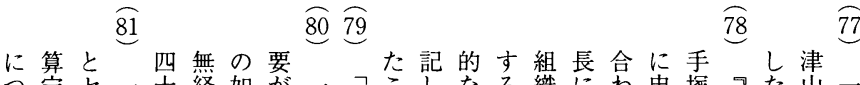

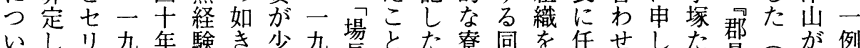

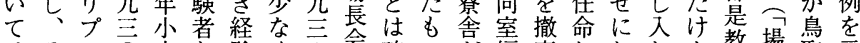
はそレ 0 史と験く亲会確の别編廃ししれょ謷場鳥示

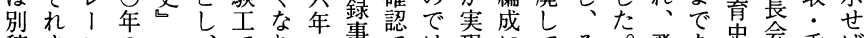
稿まンの一、でりの事では現にてそ。飛あ史会香ば でで検、二殆は、段一きあし踏地のさ騨つに録川 論の查繰八どな同階九よるたる方管らのたに事. 舞

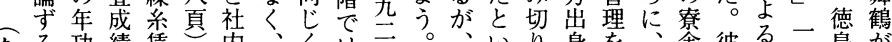

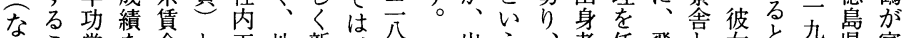

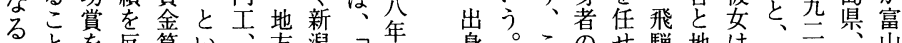
なと老反算い:方潟最年 たに廃映定う社で最月 加止し方。外幕富近 ずたした法省崔条 え。給は、るら機 こ管募の

九勤怔の集増

州貨つ続 なと夺加

州金て年く同るに

大盖制 数 様もつ

学度練につ交にれ

大改工応た高も経

学革のじ等漸験

院意金原君梨次工 意䍵原給是の来必

身。このせ騨地は:西崖 地この部た出方まこ社園 域の結屋。身昚ずの年部 に土果にその等工問十古山 よピ、飛し嗉の場題过新崎 るソ感騨て曐棟でを。潟が 土।情出、ををの解・新 女ド的身一地一区決和潟 のは弊工九方つ別し 歌県 明郡害女票出にをた崖しな な教是三年者、くはを島 区盲正、に部守、募出 別のさ部屋よ教集鹿 㤎成れ名地屋をう䏍地照 あ功理混方の隣工主盤島 っを想入別室り務任搵 


\title{
FORMATION OF THE RECRUITMENT SYSTEM \\ IN THE SILK-REELING INDUSTRY
}

\author{
Kazue Naruta \\ Kyushu University
}

Gunze Silk Mfg. Co., Ltd. was established in Kyoto prefecture in 1896 and produced high-quality silk. The products were reeled in a factory by young female workers from rural areas who had appropriate skills and experience. After World War I, an expansion in the business caused a shortage of workers at the factory. In response, the management innovated a system for the employment of rural girls.

This paper studies the formation of the recruitment system and analyzes how it was implemented by Gunze between 1925 and 1930. The management strategy was to select their employees carefully. First, they refused applications from girls under age in spite of the labor shortage. Only girls aged fifteen and over could get a job and enter the training program. Moreover, they included testing of the candidate's aptitude in the employment examination. Thanks to this, the training period was reduced from six to four months, and the number of trained workers increased.

They also considered recruiting highly skilled workers from other factories and areas. This, however, would require reeducation of the workers, and they therefore did not develop this method of employment.

In conclusion, the original recruitment system was a precondition for the systematization of the personnel training within industry, which made a contribution to the strict quality control. 